NBER WORKING PAPER SERIES

\title{
CAN PAYING FIRMS QUICKER AFFECT AGGREGATE EMPLOYMENT?
}

\author{
Jean-Noel Barrot \\ Ramana Nanda \\ Working Paper 22420 \\ http://www.nber.org/papers/w22420 \\ NATIONAL BUREAU OF ECONOMIC RESEARCH \\ 1050 Massachusetts Avenue \\ Cambridge, MA 02138 \\ July 2016
}

We are grateful to Manuel Adelino, Oriana Bandiera, Nittai Bergman, Hui Chen, Erik Hurst, Erik Loualiche, Karen Mills, Ben Pugsley, David Robinson, Antoinette Schoar, Scott Stern, John Van Reenen, Chris Woodruff, and participants at the NBER Entrepreneurship and Economic Growth Conference, Toulouse School of Economics , MIT Finance lunch, INSEAD, LSE, and Maryland Junior Finance Conference for helpful feedback. We are also grateful to the US Department of Defense for sharing data on the timing of payments from their MOCAS accounting system. Barrot recognizes the support of the Kauffman Foundation Junior Faculty Fellowship and MIT Sloan. Nanda thanks the Division of Research and Faculty Development at HBS for financial support. The views expressed herein are those of the authors and do not necessarily reflect the views of the National Bureau of Economic Research.

NBER working papers are circulated for discussion and comment purposes. They have not been peer-reviewed or been subject to the review by the NBER Board of Directors that accompanies official NBER publications.

(C) 2016 by Jean-Noel Barrot and Ramana Nanda. All rights reserved. Short sections of text, not to exceed two paragraphs, may be quoted without explicit permission provided that full credit, including (C) notice, is given to the source. 
Can Paying Firms Quicker Affect Aggregate Employment?

Jean-Noel Barrot and Ramana Nanda

NBER Working Paper No. 22420

July 2016

JEL No. E2,G2,H57,J2

\begin{abstract}
$\underline{\text { ABSTRACT }}$
In 2011, the federal government accelerated payments to their small business contractors, spanning virtually every county and industry in the US. We study the impact of this reform on county-sector employment growth over the subsequent three years. Despite firms being paid just 15 days sooner, we find payroll increased 10 cents for each accelerated dollar, with two-thirds of the effect coming from an increase in new hires and the balance from an increase in earnings. Importantly, however, we document substantial crowding out of non-treated firms employment, particularly in counties with low rates of unemployment. Our results highlight an important channel through which financing constraints can be alleviated for small firms, but also emphasize the general-equilibrium effects of large-scale interventions, which can lead to a substantially lower net impact on aggregate outcomes.
\end{abstract}

Jean-Noel Barrot

MIT

Sloan School of Management

Building E62

100 Main Street

Cambridge, MA 02142

jnbarrot@mit.edu

Ramana Nanda

Harvard Business School

Rock Center 317

Soldiers Field

Boston, MA 02163

and NBER

rnanda@hbs.edu 


\section{Introduction}

The role of financing frictions in impacting employment has received substantial interest following the 2008 financial crisis and subsequent slow recovery, where contraction in bank lending has been argued to have had a substantial impact on the real economy and particularly so on smaller firms (Greenstone et al. 2014; Chodorow-Reich 2014; Siemer 2014; Mills 2014). Policy makers interested in stimulating aggregate employment have focused on small firms' access to bank credit as a central means for alleviating potential financing constraints (Bernanke 2010; Yellen 2013).

Although a focus on bank lending is important, a more direct way that government can impact small firms' financing is through its role as their customer: federal government procurement amounts to $4 \%$ of GDP in the US and includes $\$ 100$ billion in goods and services purchased directly from small firms. Typical contracts require payment one-totwo months following the approval of an invoice, implying that these small businesses are effectively lending to the government while simultaneously having to borrow from banks to finance their payroll and working capital. Can paying small business contractors faster have a meaningful effect on their cash flows, facilitate hiring, and ultimately stimulate aggregate employment?

Theoretically, complementarities between capital and labor imply that employment is likely to be depressed when firm-level investment is held back by financing constraints. In addition, if there is a mismatch between the timing of cash flow generation and payments to labor, firms need to finance their payroll through the production process (Jermann and Quadrini 2012; Benmelech et al. 2011). A positive cash flow shock from accelerated payments could therefore have direct effects on employment for firms looking to grow, independent of the indirect effects through firm-level investment. Nevertheless, there are

reasons to also believe that faster payment might not affect aggregate employment by much, or at all: an acceleration of payment should have a negligible effect in the absence 
of financing frictions, since firms can easily fund the shortfall with bank credit. And even if affected firms grow their workforce in response to the payment acceleration, this might have negative spillovers on the employment decisions of other firms hiring from the same local labor markets. The overall effect of payment acceleration on employment therefore depends both on the intensity of financing frictions and the direction and magnitude of spillovers.

We study the impact of the federal Quickpay reform on aggregate employment through the acceleration effect it had on the "cash conversion cycle" ${ }^{1}$ of small business contractors. The reform, announced in September 2011 by President Obama, accelerated payments to a subset of small business contractors of the US federal government, reducing the time taken between invoice receipt and payment by 15 days. $\$ 64$ billion in annual contract value was accelerated and impacted a set of small businesses across virtually every US county due to the massive footprint of federal government procurement.

A unique element of our setting is the fact that despite being extensive in coverage, the reform was focused on firms that were small business contractors to the federal government who were not already being paid in 15 days. This provides us with useful cross-sectional variation in the intensity of treatment across county-sector cells and is therefore a key of our identification strategy. Our approach also allows us to contrast the effect of treatment on different local labor markets and hence examine, for example, how it varied across counties where unemployment rates were particularly high at the time the reform was implemented, or where bank credit was particularly scarce. Finally, we are able to separate the direct effects of the reform from potential spillovers on firms that did not directly benefit from the reform, allowing us to study the components to the overall effect of this large-scale intervention.

\footnotetext{
${ }^{1}$ The cash conversion cycle refers to the number of days of working capital need to be financed. For example, if the firm has to pay cash on delivery of inputs, which sit in inventory for an average of 15 days, and on average, the firm is paid by its customers 30 days after the sale, then the cash conversion cycle is 45 days.
} 
We find a very substantial impact of accelerated payment on small firms, despite the acceleration being a 'mere 15 days'. We estimate that on average, each accelerated dollar of sales led to almost 10 cent increase in payroll, with two-thirds of the increase coming from new hires and the balance third from increased earnings per worker. Our estimates suggest that the direct effect of the policy was to increase annual payroll by $\$ 6$ billion, and to create just over 75,000 additional jobs over the three years following the reform. We show that there are no prior trends, and that the effects are not driven by county-sector exposure to government contracts or to small businesses, but by exposure to accelerated contracts only. Consistent with the acceleration of the 'cash conversion cycle' driving payroll growth, we find the effect to be strongest in sectors where receivables account for a larger share of assets and in counties where financing frictions are more severe for small firms.

Importantly, however, we also document substantial crowding out of employment growth among non-treated firms. Since the increased demand for labor from treated firms in tighter labor markets also exerts pressure on wages, this makes it relatively harder for non-treated firms to hire, leading them to grow employment slower. We find negative spillovers to be stronger within sector than across sectors. We also provide evidence of actual job flows from low to high treatment sectors. Finally, we show that negative spillovers are concentrated in local labor markets with comparatively lower unemployment rates at the time of the reform.

Overall these findings highlight a new channel through which financial frictions affect firm-level employment. Nevertheless, we find that while the federal payment acceleration reform did stimulate employment in areas with high unemployment at the time of its introduction, it had little or no effect elsewhere. This highlights how the general equilibrium effect of relaxing financing constraints in terms of employment growth might be substantially lower than partial equilibrium estimates might suggest, due to competition for inputs in common factor markets (Acemoglu 2010). 
Our results are related to several strands of the literature. We first contribute to a growing stream of research focusing on the relationship between financial frictions and employment. ${ }^{2}$ Relative to the few other studies in this area, our experiment allows us to rigorously study the direct effects of relaxed financial constraints on aggregate employment, something that is harder to do when looking at other shocks such as those to bank credit, which tend to also be correlated with macroeconomic conditions. Since we can measure the dollar-magnitude of treatment, we are able to estimate the cash-flow elasticity of payroll, and thereby infer the intensity of financial frictions facing small businesses. Another important contribution of our work is therefore the ability to compare the elasticity of the payroll response for small businesses to other estimates gleaned from studying large, publicly traded firms. In addition to studying the direct effects of the treatment, our context also provides a unique opportunity to study crowding out effects on non-treated firms, due to the targeted nature of the treatment.

Secondly, our work sheds light on the implicit cost of trade credit, a question that has only recently begun to be examined in detail. By being paid weeks after the sale of a good or a service, firms effectively provide short-term corporate financing to their customers. Such inter-firm financing is referred to as trade credit and, in aggregate, is three times as large as bank loans and fifteen times as large as commercial paper in the US. ${ }^{3}$ Trade credit claims, recorded as accounts receivable on firms' balance sheets, are typically seen as short-term, liquid, low-risk claims that should be very easy to pledge, and that should not constrain firm growth. Yet recent research as found that long payment terms forces financially constrained firms to cut back investment (Murfin and Njoroge 2014) and exposes them to liquidity risk (Barrot 2015). ${ }^{4}$ Our work shows that trade

\footnotetext{
${ }^{2}$ The effect of financing frictions on capital investment has been studied extensively, starting with Fazzari et al. (1988), who find a strong positive relationship between cash flows and investment. Subsequent studies have complemented these findings using exogenous variations in cash flows including Blanchard et al. (1994), Lamont (1997), Rauh (2006), Faulkender and Petersen (2012), variations in collateral such as Chaney et al. (2012), or structural models including Whited (1992).

${ }^{3}$ As of September 2012, according to the US Flow of Funds Accounts.

${ }^{4}$ Other contributions to the literature on trade credit include Petersen and Rajan (1997), Biais and
} 
credit provision also constrains employment growth, even when the debtor is a low-risk customer such as the federal government. ${ }^{5}$

Finally, our findings build on the literature assessing the role of policy intervention targeting businesses in the US, most of which has focused on fiscal policies including bonus depreciation (House and Shapiro 2008; Zwick and Mahon 2016) or tax refunds (Dobridge 2016) so far. We evaluate the effect of the federal payment acceleration reform which was motivated by the need to stimulate job growth in the wake of the Great Recession. Related to this, our work is among the first to examine the role of government as a customer and its implications for the private sector. ${ }^{6}$ We show that targeting the working capital of small businesses can be a potentially effective way for policy makers to alleviate financing constraints but this needs to be balanced against the potential crowding out of firms that are not direct contractors to the government.

The rest of the paper is structured as follows. In Section 2, we provide an overview of the Quickpay reform and sketch a simple theoretical model that demonstrates how accelerated payments impact labor market outcomes in the presence of financial frictions. In Section 3, we describe our identification strategy and provide an overview of the data we use to study the effect of Quickpay. Section 4 outlines our results, and relates the results from our regressions to the theoretical model to provide a perspective on the magnitudes. Finally, Section 5 concludes.

Gollier (1997), Burkart and Ellingsen (2004), and Murfin and Njoroge (2014) Wilner (2000), DemirgucKunt and Maksimovic (2001), Frank and Maksimovic (2005), Cunat (2007), Giannetti et al. (2011), Antras and Foley (2011), Dass et al. (2011), Kim and Shin (2012), Klapper et al. (2012), Garcia-Appendini and Montoriol-Garriga (forthcoming)

${ }^{5}$ In practice, there impediments in the pledgeability of government trade credit claims. We provide more details below.

${ }^{6}$ Other studies include Liebman and Mahoney (2013), Cohen and Malloy (2014), Ferraz and Finan (2015) Goldman (2015). 


\section{Financing Labor Inputs}

\subsection{Theoretical Considerations}

In the presence of adverse selection (e.g., Stiglitz and Weiss (1981)) or moral hazard (e.g., Holmstrom and Tirole (1997)), firms may be unable to raise outside finance and may consequently need to forgo positive net present value projects. The traditional view of labor inputs is that they are 'self-financing', so that such financing constraints are thought to impact a firm's hiring decisions only indirectly, through the effect they have on capital investment decisions. In this case, a relaxation in financing constraints will lead to more hiring when labor and capital are complements, but might lead to a fall in employment when capital and labor are substitutes, as evidenced in Chaney et al. (2016). Recent work has highlighted that employment decisions might still be affected by frictions in the capital markets if labor is not a variable factor of production but rather has a fixed, or quasi-fixed cost component (Hamermesh 1989; Hamermesh and Pfann 1996). These adjustment costs could emerge because of hiring and training costs, for instance.

Aside from adjustment costs, however, financing frictions can have a consequential effect on employment when firms face a constraint on working capital (Jermann and Quadrini 2012). This is particularly true among small or young firms that are in growth mode, as the mismatch between the timing of cash flow generation and payments to labor requires firms to finance their payroll through the production process - in advance of getting paid - and means that firms may have to cut back on hiring even in the presence of customer demand and adequate labor supply, due to an inability to pay workers in advance of receiving cash for their product or service. Survey evidence indeed suggests that over $90 \%$ of small businesses pay their employees twice a month or more frequently, with nearly half paying their employees weekly (Dennis 2006).

In the absence of financing frictions, a firm will be able to borrow fully against future 
cash flows, leading any change in the working capital cycle to have virtually no effect on a firm's hiring decisions. However, young firms without a history of cash flows or a well established credit rating can face significant challenges in accessing a working capital line of credit from banks. An alternative for them is to turn to factoring companies, who buy accounts receivable in exchange for cash upfront. In practice, however, the negative stigma associated with factors leads small firms to go to them only as a last resort. ${ }^{7}$

One might argue that government contractors should easily find external financing for their receivables in the form of working capital loans or factoring. This is not necessarily true for at least two reasons. First, in order to obtain a security interest on a government receivable, the credit provider must give timely written notice of the assignment to both the agency's contracting officer and its disbursing officer, and obtain written confirmation from both under the Federal Government Assignment of Claims Act (FACA). Moreover, while it is probably true that the government is a safer customer than many firms in the economy, typical government contracts include provisions allowing the purchasing agency to arbitrarily terminate the contract for convenience or for failure to obtain necessary budgeting.

In the presence of financing frictions, even small improvements in cash collection can have large direct effects on hiring due to the multiplier effect of working capital. To see why, note that a firm with $\$ 1$ million of sales being paid 30 days after delivering its product always has $\$ 80,000$ of cash 'tied up' in receivables at any moment in time. A shift in the payment regime from 30 days to 15 days therefore permanently unlocks $\$ 40,000$ of cash for the firm on an ongoing basis. In the extreme where the firm was only able to support growth through internal cash flow, this will allow the firm to double in size, to $\$ 2$ million, showing how seemingly small improvements in the working capital position for

\footnotetext{
${ }^{7}$ Indeed customers have been known to pull back on demand upon learning that receivables were factored as this could suggest firms are on their last legs and hence can lead to issues with supply going forward. In addition, non-recourse factoring (where the factor takes on the full counter-party risk) has become far less prevalent for small firms, so that even if small firms did use factors, this would not free up a large amount of cash for them to put towards firm growth.
} 
constrained firms can have consequential effects for growth in sales and in payroll.

We formalize this intuition with a one-period model featuring constraints on working capital finance. Firms hire labor, produce and sell continuously but only receive payments after selling their output, so that they have to finance their inputs in advance. To do so, they can raise money up to a fraction of future profits (pledgeable profits). The economy consists in two sets of firms $t$ and $u$, with respective mass $\mu$ and $1-\mu$, that only differ in the amount of working capital they need to finance upfront. ${ }^{8}$ Both sets of firms $i \in(t, u)$ have the same decreasing returns to scale technology in labor:

$$
Y=L^{\alpha}
$$

where $\alpha<1$ captures the decreasing returns to scale. Firms maximize profit:

$$
\max _{L} \Pi(L)=p Y-w L-r \gamma_{i} w L
$$

subject to the working capital constraint (Jermann and Quadrini 2012):

$$
\gamma_{i} w L \leq \xi \Pi(L)
$$

where we take output as the numeraire such that $p=1$, and $w$ is the competitive wage. $\gamma_{i}$ is the number of days of inputs firms of type $i$ have to finance in advance, as a fraction of the number of days in the year. $\xi$ is the maximum external finance that can be taken as a fraction of end-of-period profits. We borrow this reduced form representation of the constraint on external financing from Jermann and Quadrini (2012), and note that $\xi$ could either be driven by the reluctance of financiers to lend, or of firms to borrow. $r$ is the interest rate on the working capital loan. The first order conditions for the maximization

\footnotetext{
${ }^{8}$ Having two sets of competitive firms in the model allows us to separately consider the effect of payment acceleration on treated firms and other firms.
} 
of profit with respect to labor is given by:

$$
L_{i}^{*}=\left(\frac{w}{\alpha} \frac{1+\lambda \xi+r \lambda \gamma_{i}}{1+\lambda \xi}\right)^{\frac{1}{\alpha-1}}
$$

where $\lambda$ is the Lagrange multiplier on the working capital constraint, which captures the shadow value of cash inside the firm - the units of profits that can be obtained by relaxing the constraint. Assuming the constraint is binding, we can rewrite this as:

$$
L_{i}^{*}=\left(w \frac{\gamma_{i}+\xi+r \xi \gamma_{i}}{\xi}\right)^{\frac{1}{\alpha-1}}
$$

which shows that for a given level of the competitive wage, labor demand is increasing in the level of pledgeability of profits $\xi$ and decreasing in $\gamma_{i}$, the working capital the firm needs to finance. Importantly, equation (5) shows that even when $\xi$ is relatively large, so that firms are able to borrow against a substantial share of their future profits, a small change in $\gamma_{i}$ can nevertheless have a large impact on the change in firm-level employment.

We next consider the households' problem and assume they maximize the following utility function:

$$
U(C, L)=C-\zeta \frac{L^{1-\frac{1}{\theta}}}{1-\frac{1}{\theta}}
$$

where $C$ is the numeraire, $L$ is labor supply, subject to the budget constraint:

$$
C \leq w L+\Pi(L)
$$

The first order conditions of this problem allow us to express labor supply as:

$$
L_{s}^{*}=\left(\frac{w}{\zeta}\right)^{-\theta}
$$

where $\theta$ is the labor supply elasticity. We finally obtain the equilibrium wage $w^{*}$ from 
the market clearing condition, by equating demand and supply on the labor market. Our empirical analysis considers the response of employment to a change in the number of days receivables. Within the model, we can compare the change in the optimal quantity of labor when going from $\gamma_{i, 1}$ prior to Quickpay to $\gamma_{i, 2}$ afterwards. We express employment growth for treated firms $(i=t)$ across the two steady states, prior and after Quickpay as

$$
\frac{L_{t, 2}^{*}}{L_{t, 1}^{*}}=\left(\frac{\gamma_{t, 2}+\xi+r \xi \gamma_{t, 2}}{\gamma_{t, 1}+\xi+r \xi \gamma_{t, 1}}\right)^{\frac{1}{\alpha-1}}\left(\frac{w_{2}^{*}}{w_{1}^{*}}\right)^{\frac{1}{\alpha-1}}
$$

The first term on the right hand side of equation 9 captures the effect of higher labor demand triggered by the reform. The second term captures the negative effect such higher demand has on demand through the change in wages. For untreated firms, $\gamma_{u, 2}=\gamma_{u, 1}$ and employment growth reduces to

$$
\frac{L_{u, 2}^{*}}{L_{u, 1}^{*}}=\left(\frac{w_{2}^{*}}{w_{1}^{*}}\right)^{\frac{1}{\alpha-1}}
$$

which is decreasing in wage growth. Untreated firms are thus negatively affected by the increase in wage triggered by the higher demand of treated firms.

The nice feature of equation 9 is that we can calibrate all parameters but $\frac{L_{i, 2}^{*}}{L_{i, 1}^{*}}$ and $\xi$, the pledgeability constraint. The empirical exercise we present below delivers $\frac{L_{i, 2}^{*}}{L_{i, 1}^{*}}$, thus allowing us to pin down $\xi$. Our findings therefore shed light on the intensity of financing constraints facing firms in the US at the time of the Quickpay reform that we describe next.

\subsection{The Quickpay Reform}

Although the economy began recovering from the trough of the Great Recession in June 2009, employment growth was sluggish, in what is now commonly referred to as the 'jobless recovery'. Bank lending following the financial crisis also continued to lag, particularly 
for small businesses. Alternative channels of finance were expensive, with interest rates typically upwards of 25\% even when these firms could access credit (Mount 2012).

Faster payment to small business contractors of the federal government was initially promoted by the President's Council on Jobs and Competitiveness and supported by the Small Business Administration (SBA). The main motivation for undertaking this payment acceleration reform was to stimulate job creation as clearly evidenced in the White House press release announcing the reform. ${ }^{9}$ The underlying idea was that "small businesses are the primary engine of job creation and job growth". Given that the Federal Government purchases approximately $\$ 100$ billion each year for goods and services from small businesses, accelerating payments was intended to allow them to "reinvest that money in the economy and drive job growth".

In 2011, US federal agencies started accelerating payments to their small business contractors, a reform named Quickpay. Prior to the reform, payments were typically made within 30 days from when an agency received an invoice, in accordance with the Prompt Payment Act. ${ }^{10}$ If an agency did not pay a vendor the amount due by the required payment date, it was required to pay the vendor a late-payment interest penalty. Under the new policy, agencies were asked to make payments as quickly as possible and within 15 days of receiving proper documentation, including an invoice for the amount due and confirmation that the goods or services have been received and accepted. ${ }^{11}$ The reform was formally announced on September 14, 2011 with the goal of achieving payments acceleration in all federal agencies by November 1, 2011. ${ }^{12}$ However, some agencies anticipated the reform by a few months. In particular, the Department of Defense, the largest contributor to federal procurement by far, started accelerating payments as of April 27, 2011. ${ }^{13}$ Accelerated dollars over the subsequent three years (our window of analysis) amounted

\footnotetext{
${ }^{9}$ Getting Money to Small Businesses Faster, White House Press Release, 2011

${ }^{10}$ Chapter 39 of title 31 of the United States Code

${ }^{11}$ See Memorandum M11-32 of the Office of Management and Budget, 2011

${ }^{12}$ See Memorandum M11-32 of the Office of Management and Budget, 2011

${ }^{13}$ See Memorandum 2011-O0007 of the Office of the Under Secretary of Defense, 2011.
} 
to $\$ 64$ billion per year.

For the purpose of this policy, small businesses are defined according to SBA's thresholds. These thresholds vary significantly across industries: the upper limit varies from 0.75 million to 38.5 million in annual receipts, or between 100 and 1500 employees. ${ }^{14}$ The contracting officer in any given federal agency is in charge of checking whether the contractor is a small business firm and whether it is therefore eligible to accelerated payments. While all contracts awarded to small businesses were accelerated after the reform, some contracts were already typically paid sooner than 15 days, and remained unaffected by the policy change. More precisely, government contracts fall under two broad categories: fixed-price and cost-plus. Under fixed-price contracts, contractors agree to deliver the product or service at a pre-negotiated price. Under cost-plus contracts, contractors are paid for their expenses up to a set limit, plus profit. ${ }^{15}$ The Department of Defense, which accounts for approximately two thirds of federal procurement, was already paying its cost-plus contracts within 15 days. ${ }^{16}$ In the rest of the paper, we use the term "ineligible" or "cost-plus" contracts to refer to DOD cost-plus contracts that were being paid within 15 days even before the reform. ${ }^{17}$ As we discuss later, this heterogeneity across contract types' exposure to the reform allows us to tightly identify the effect of payment acceleration on labor market outcomes. Table A.2 shows the distribution of cost-plus and fixed-price contracts across industries and firm-type. We discuss the specifics of our identification strategy in the following section.

\footnotetext{
${ }^{14}$ For more details on these thresholds, see https://www.sba.gov/content/small-business-size-standards

${ }^{15}$ For further analyses of these two contract types, see Horton (2008), for instance.

${ }^{16}$ See Subpart 232.906 of the Department of Defense Supplement to the Federal Acquisition Regulation (DFARS), 48 CFR Chapter 2

${ }^{17}$ With a slight abuse of notation, we therefore group non-DOD cost-plus contracts with fixed-price contracts.
} 


\section{Empirical design}

\subsection{Identification Strategy}

To understand the change in labor market outcomes driven by the Quickpay reform, we start with the following specification at the county-sector-year level:

$$
\log Y_{s c t}=\gamma_{s t}+\lambda_{c t}+\eta_{s c}+\beta_{1} \cdot\left(\text { Treatment }_{s c} \cdot d_{t}\right)+\beta_{2} \cdot X_{s c t}+\epsilon_{s c t}
$$

where $Y_{\text {stc }}$ is either total payroll, total employment or average earnings, measured in county $c$ and sector (or industry) $s$ at date $t=\{2011 Q 1,2014 Q 1\} . d_{t}$ is a dummy for observations in 2014Q1. Treatment ${ }_{s c}$ is defined as $\frac{F A_{s c}}{Y_{s c 2011}}$ where $F A_{s c}$ is the average quarterly amount of eligible government contracts to be performed in a given county $\times$ sector between 2009Q1-2011Q1. This includes all contracts awarded to small businesses, excluding cost-plus contracts awarded by the DOD, which were already paid within 15 days. $Y_{s c 2011}$ is quarterly payroll measured 2011Q1. Our measure of treatment therefore captures the intensity of exposure to "Treated Contracts" in the quarter preceding the reform. As can be seen in Figure 1, treatment spans virtually every county in the US and exhibits substantial within-state variation, even without accounting for within county variation at the sector level. Moreover, since we measure treatment at the county-sector-year level, this allows us to identify the effect of the treatment while including fixed effects at sectoryear level $\left(\gamma_{s t}\right)$, the county-year level $\left(\lambda_{c t}\right)$ and county-sector level $\left(\eta_{s c}\right) . X_{s c t}$ is a set of time-varying controls at the industry-sector level including government spending at the county-sector level.

As in Card (1992) and Angrist and Pischke (2012), given that we analyze data for two periods, we collapse equation 11 into the following equation in first-differences:

$$
\Delta \log Y_{s c}=\gamma_{s}^{\prime}+\lambda_{c}^{\prime}+\beta_{1} \cdot \text { Treatment }_{s c}+\beta_{2} \cdot X_{s c}^{\prime}+\epsilon_{s c}^{\prime}
$$


where $\Delta \log Y_{s c}$ is the change in $\log$ payroll from 2011Q1 to 2014Q1. The set of controls, $X_{s c}^{\prime}$, include average quarterly government spending at the county-sector level normalized by 2011Q1 payroll, as well as the unemployment rate, correlation of employment growth with US employment growth, log employment, log average earnings, past three year employment growth, past three year earnings growth, past ten year employment growth, log average establishment size, and the share of small establishments, all measured as of 2011Q1.

The main coefficient of interest, $\beta_{1}$, measures the sensitivity of payroll growth from 2011Q1 to 2014Q1 to the county-sector share of accelerated contracts in total payroll. Because $\Delta \log Y_{s c}$ approximates $\frac{Y_{s c 2014}-Y_{s c 2011}}{Y_{s c 2011}}$, and recalling that Treatment $t_{s c}=\frac{F A_{s c}}{Y_{s c 2011}}$, $\beta_{1}$ can also be interpreted as a cash-flow elasticity of payroll, namely, the additional $\$$ of payroll spent for each accelerated $\$$ of sales $\left(F A_{s c}\right)$.

Our identifying assumption, which is analogous to the parallel trends assumption, is that conditional on controls, treatment is orthogonal to labor market changes for the control group. There are several potential concerns about this assumption. First, countysectors with high treatment intensity might be more exposed to government spending, and might therefore be on a different trend. We address this concern in several ways. We control for overall exposure to government contracts in all regressions. We also control for both ten-year employment growth as well as the correlation of employment growth in each county-sector with US employment growth in the past ten years. Finally, in placebo regressions, we check that county-sector exposure to government contracts that were not accelerated, either because they were already paid within 15 days, or because they were awarded to large businesses, does not drive employment growth.

Another concern is that county-sectors with high treatment intensity might be more exposed to small businesses, who might also have a different sensitivity to the business cycle. In addition to controlling for long term employment growth and correlation with the business cycle, we also control for the share of small establishments and the average 
size of establishments in all regressions. If exposure to small businesses is driving the results, these variables should absorb the effect. In addition, we directly check in placebo regressions whether government contracts awarded to small businesses that were not accelerated following Quickpay, because they were already paid within 15 days, had any impact on payroll growth.

One might also worry that procurement policy might have changed after the reform in ways that could explain the results, irrespective of the payment acceleration. In particular, one might worry that firms in areas highly exposed to treatment might have been awarded significantly more government contracts after the change. We check in Appendix Table A.1 whether county-sector exposure to treatment is associated with a change in average quarterly government contracts in the three years after Quickpay relative to the pre-period, normalized by 2011Q1 payroll. We find that this is not the case, so that results are unlikely to be driven by a surge of government contracts targeting areas where payments were also accelerated. ${ }^{18}$

A related concern is that other contract terms might have changed endogenously as a results of the reform. In particular, prices might have gone down as a result of the more aggressive bidding by small businesses after payments are accelerated. One may wonder whether the drop in prices could offset the increased liquidity associated with the acceleration. If it were the case, then this would go against finding any effect of the reform on payroll. While we do not observe prices, we check whether government auctions are more likely to be awarded to small businesses and find no evidence for this. ${ }^{19}$ Alternatively, if the time between invoicing and payment was used by federal agencies to

\footnotetext{
${ }^{18}$ We also re-run our regressions using a measure based on contemporaneous acceleration of contracts and find the results to be unchanged. Note, however, that we do not attempt to distinguish how much of the effects we are capturing are coming from firms that were government contractors before the introduction of Quickpay and benefit from the payment acceleration, of from firms that became government contractors or were created after its introduction.

${ }^{19}$ Moreover, while small businesses can theoretically revert to their reservation profits after Quickpay by lowering prices, they might still grow payroll and employment in the process, thereby achieving the same level of profit with higher employment.
} 
check the quality of the goods being delivered, the shorter time period might allow small businesses to produce lower quality output, and might lead the government to shift its procurement away from them (Breza and Liberman 2016). Again, this would probably go against finding any positive effect of Quickpay on small business payroll.

\subsection{Data}

We measure labor market outcomes using data from the US Census Quarterly Workforce Indicators (QWI), derived from the Longitudinal Employer Household Dynamics program (LEHD). For each two-digit sector ${ }^{20}$ in each county, we obtain quarterly payrolls, employment and average earnings per worker. ${ }^{21}$ The focus of our analysis is on the change in these outcomes from 2011Q1 to 2014Q1. The data allow us to separately analyze job creations and separations, as well as the earnings of new and existing workers. We also take advantage of a recently released supplement to the QWI, the job-to-job flows data. In each quarter, we obtain the number of workers leaving a job in a given State and sector to start a new one in some other State and sector. Control variables at the countysector level are derived from the QWI and the County Business Patterns (CBP) data set published by the US Census Bureau and based on the Longitudinal Business Database (LBD).

We measure exposure to the treatment using publicly available data on government contracts. The Federal Funding Accountability and Transparency Act of 2006 required the Office of Management and Budget to create a public website describing each federal award in great details, including contracts, grants, direct payments and loans. This website was launched in 2007 and includes archives from the Federal Procurement Data System (FPDS) since 2000. For each contract, we obtain the contract identifier, amount

\footnotetext{
${ }^{20}$ Sectors are defined according to the National American Industry Classification System (NAICS).

${ }^{21}$ Unfortunately, these data do not allow us to measure wages. Earnings per worker are defined as the product of hourly wage and the number of hours of work per month.
} 
and date when the contract is signed, the contract type (cost-plus or fixed-price), the name of the contractor and its six-digit sector, whether the contractor is a small business or not, and the zip code where the place is to be performed. ${ }^{22}$ As noted above, these data allow us to create a county-sector level measure of exposure to treatment, based on the average quarterly value of contracts awarded to small businesses in that cell over the period 2009Q1-2011Q1, scaled by payroll in that cell in 2011Q1.

FPDS data does not incorporate payment speed information. To verify that the reform was effectively implemented, we obtained proprietory cash flow information from the Department of Defense's main payment system, the Mechanization of Contract Administration Services (MOCAS). For all receipts processed from 2010Q3 to 2014Q3, we obtain the date between receipt and payment as well as contract characteristics including the contract identifier that allow us to merge this information with FPDS data. Appendix Figure A.1 presents average payment terms, measured as the difference in days between the receipt and payment and the invoice around the implementation of the acceleration. From Panel A, we see that payment terms faced by small businesses with fixed-price contract experience fall sharply. By contrast, Panel B shows that payment terms faced by large businesses do not change. Moreover, small businesses with cost-plus contracts are already paid within 15 days before the reform and experience little or no acceleration on average. We also show in Appendix Figure A.2 that the aggregate accounts payable of the federal government, including agencies for which we do not have the contract level descriptive data, go down starting in fiscal year $2011,{ }^{23}$.

Table 1 provides descriptive statistics for our main variables. As can be seen from Table 1, on average, the quarterly dollar value of accelerated contracts was $2.3 \%$ of the county-sector's 2011Q1 payroll. The average county-sector has 2,203 employees, aver-

\footnotetext{
${ }^{22}$ We also obtain the place of location of the contractor. While this is a less well measured data point, we find similar results when we use this information instead, most likely because both locations are the same in a vast majority of cases.

${ }^{23}$ Fiscal year end on September 30.
} 
age annual earnings per worker of $\$ 32,485$ and average payroll of close to $\$ 100$ million. County-sectors in the sample have on average 136 establishments in 2011, of which 15 had government contracts, and 8 had government contracts that were accelerated. Panel B of Table 1 also shows that accelerated contracts spanned every industry in our sample. Appendix Table A.2 further details the average annual \$ value of of government contracts awarded to small and large businesses. Manufacturing and Professional Services account for over half the $\$$ value of accelerated contracts, with Construction, Administration and Wholesale also accounting for a further third of the contract value. Appendix Table A.3 and A.4 provide more detailed description of the 4-digit NAICS sectors and county-by2-digit NAICS cells that experienced the highest and lowest acceleration, respectively. Overall, treatment seems spread out across sectors and geographical areas.

\section{Results}

\subsection{The Direct Effect of Accelerated Payments}

We first estimate the effect of the payment acceleration on payroll. As we show in equation 12, we aggregate both the exposure to the shock and the labor market outcomes of interest to the county-sector level. We consider the three-year change in total payroll from 2011Q1 to 2014Q1 as a function of the exposure to treatment. Table 2 presents our baseline results. Across specifications, the coefficient on treatment is positive and significant. The introduction of controls does attenuate the coefficient slightly, which remains stable around 0.1. In the most conservative specifications which includes the full set of controls as well as industry- and county fixed effects, we obtain a coefficient of 0.097 (Column 5).

Given that treatment is $2.3 \%$ on average, our findings suggest that county-sector payrolls increase by $0.23 \%$ on average following the payment acceleration. Panel B reports the magnitudes in terms of a standardized treatment, and shows that a one standard 
deviation increase in treatment corresponds to a $1.1 \%$ increase in payroll. To get a sense of the magnitude of the effect of Quickpay on total payroll, we multiply the exponential of our coefficient, 0.097, times the value of treatment, by the $2011 \mathrm{Q} 1$ payroll for every county-sector. We sum the result across county-sectors and find a total of $\$ 1.5$ billion increase in quarterly payroll, or $\$ 6$ billion in annualized terms. Reassuringly, this is close to the estimate reached by using $10 \%$ of the $\$ 64$ billion value of contracts eligible to the acceleration.

Our estimate implies that payrolls increase by 10 cents for each accelerated dollar of sales. Measuring the implied cash-flow elasticity of payroll can be done by recognizing that a dollar of sales with the government prior to Quickpay requires 30 days of working capital. This implies that $30 / 365=8$ cents are tied up in accounts receivables at any point in time. Moving to 15 days permanently frees up 4 cents of cash flows that can be compared with the 10 cents in additional payrolls. This elasticity of 2.5 is higher than the few existing estimates from prior work focusing on publicly listed firms in Compustat and summarized in Schoefer (2015) who shows they range between 0.2 and 1. This should not come as a complete surprise given that the focus of our study is on small businesses that face more severe financing frictions, and that the cash-flow shock we consider is more permanent than what other studies have considered - and might thus trigger a more significant response.

We provide several robustness tests for our baseline specification that we present in the Appendix. In Appendix Table A.5, we run a differences-in-differences specification analogous to Equation 11, including a time dimension in the data. As shown in Equation 11, this allows us to also control for industry-year, sector-year and county-sector fixed effects. The magnitudes of coefficients are almost unchanged, suggesting that our specification in first-differences accounts for the relevant sources of unobserved heterogeneity. Panel B shows that the results hold when we use a dummy for high treatment rather than the continuous version of treatment that we use in the baseline analysis. In Panel 
A of Appendix Table A.6 we show that measuring treatment based on ex post accelerated contracts as opposed to our exogenous measure of exposure to acceleration based on pre-period contracts yields similar magnitudes. Finally in Appendix Table A.7 we run our specifications at the county-by-4-digit NAICS to include tighter industry fixed effects. The results are unchanged.

\subsubsection{Dynamics and Falsification Tests}

We next examine the dynamics around the reform. Table 3 replicates columns 5 in Table 2, but with different long-difference intervals so as to analyze the evolution of the effects between 2009 and 2014. Column 1 of Table 3 looks at the change in payroll from 2009Q1 to 2011Q1 and column 2 looks at the change from 2010Q1 to 2011Q1. Both Columns 1 and 2 show that, there is no evidence of a pre-trend. Columns 3-5 look at the post-period, with increasing windows from the introduction of the reform. Column 3 shows that about half the measured effect in Table 2 was realized in the first year, although this is not precisely estimated. Further, but diminishing marginal growth is seen in the subsequent two years. These dynamics are reassuring, as they highlight that the timing of the effects are consistent with the accelerated payments causing the increase in payroll.

From an identification perspective, a nice feature of the Quickpay reform was that it accelerated a subset of small business contracts and left all large business contracts unchanged. This allows us to run falsification tests where we can split total government spending at the county-sector level into its constituent parts and see whether county-sector exposure to DOD cost-plus contracts awarded to small business or contracts awarded to large business contracts are also associated with payroll growth. If this were so, it would suggest that something related broadly to government exposure, or a particular contracttype, rather than the Quickpay reform per se, was responsible for our findings. We report the results from these falsification regressions in Table 4, which are similar to those in 
Table 2. As seen in Table 2, only exposure to fixed-price contracts awarded to small businesses leads to an increase in aggregate payroll. Exposure to the other three types of government contracts lead to precisely estimated zero effects. This provides compelling evidence that it is exposure to accelerated contracts as opposed to other correlates that is driving the payroll growth.

\subsubsection{Heterogeneous Treatment Effects}

The results in Table 3 and 4 together document that accelerated payments can stimulate payroll growth. We next check whether the effects are larger in some industries and areas. Since our treatment variable is scaled by payroll, we would expect to find a larger effect in industries where payroll is larger relative to sales. For the same level of our treatment variable, a firm is more likely to grow if accelerated contracts are a larger share of its total sales - which our treatment variable will capture if the ratio of payroll to sales is larger. We find that this is the case in Column 1 of Table 5, where we interact the treatment variable with a dummy for high payroll-to-sales sectors, based on BEA industry accounts. Moreover, if these effects are driven by the faster 'cash conversion cycle', we would expect the effects to be stronger in sectors where receivables form a larger share of total assets. If a firm needs a lot of other assets to operate, then a reduction in its accounts receivable is unlikely to have a major effect. This is what we find in Column 2 of Table 5, where we interact the treatment variable with a dummy for high receivables-to-assets sectors, based on Compustat.

Moreover, we would expect the effects to be stronger where financing frictions are more severe. In Columns 3 and 4 of Table 5, we estimate the coefficient on the treatment variable separately in industries with high and low degrees of pledgeability, measured with the ratio of fixed assets to assets obtained from Compustat, and in counties with high or low issuances of small business loans per establishments in 2010, based on Community Reinvestment Act and County Business Patterns data. We find the effects to be 
pronounced in low pledegeability industries and counties with fewer small business loans, where credit availability is likely to be lower. This provides strong evidence that the effect of payment acceleration on payroll is driven by a relaxation in financing constraints.

\subsubsection{Employment Response}

The QWI data allow us to separate payroll growth into the share arising from employment growth versus growth in average earnings. We therefore study the degree to which payroll increased at the extensive margin (employment growth) versus the intensive margin (earnings growth). ${ }^{24}$ We report the results in Table 6 , which is equivalent to Table 2, except that $\Delta \log Y_{s c}$ now measures the change in total employment and the change in average earnings between 2011Q1 and 2014Q1 at the county-sector level. As with Table 2, the coefficients attenuate slightly with the inclusion of fixed effects. They remain statistically significant and economically meaningful even with the inclusion of the full set of fixed effects, as evidenced in Column 5. Comparing the magnitude of the coefficients in Panel A and Panel B to those found in Table 2, we conclude that about two-thirds of the change in payroll growth comes from the extensive margin through growth in employment, with the remaining third arising at the intensive margin from a change in earnings. Such an increase in employment might be driven by an increase in new hires or a decrease in separations. We show in Appendix Table A.8 both hiring and separations go up following the payment acceleration, with the former growing faster than the later, leading to more net hires. Finally, to get a sense of the magnitude of the effect of Quickpay on total employment, we multiply the exponential of our coefficient, 0.062, times the value of treatment, by 2011Q1 employment for every county-sector. We sum the result across county-sectors and find a total of just over 75,000 new jobs.

\footnotetext{
${ }^{24}$ Again, earnings growth can either be explained by a increase in wages or an increase in hours worked, and our data does not allow us to differentiate between the two.
} 


\subsubsection{Extent of Financing Constraint Implied by Estimates}

As noted in Section 2 above, an attractive feature of our setting is that we are able to map our reduced form estimates to the simple model outlined in Section 2, and thereby infer the size of financing frictions facing the small businesses in our setting. Recall that Equation 9 allows us to estimate the degree of constraints faced by firms, because it only depends on employment growth and the change in $\gamma_{i}$ that we both observe empirically, model parameters that we can calibrate with standard values, as well as $\xi$, the pledgeability constraint, that we can therefore infer. More precisely, we assume that for the subset of firms $t$ affected by the change, $\gamma_{t, 1}=30 / 365=.8$ and $\gamma_{t, 2}=15 / 365=.4$. By contrast, for the subset of firms $u$ unaffected by the reform, $\gamma_{u, 1}=\gamma_{u, 2}=30 / 365=.8$. We follow Basu and Fernald (1997) and assume $\alpha=0.85$. We also assume a standard elasticity of labor supply of 0.5 . We set $r$ to $4 \%$ to reflect rates on short term loans according to the Survey of Terms of Business Lending as of $2011 .^{25}$ Table 7 presents the values for employment growth implied by our theoretical framework as a function of the pledgeability constraint $\xi$.

Our reduced form estimates measure the firm response if $100 \%$ of payroll was accelerated. Given that the average share of payroll in total sales is $33 \%$ in the BEA input-output data, a firm with $100 \%$ of its sales affected by the reform would experience a $0.062 * 3=19 \%$ increase in employment. As can be seen from Panel A of Table 7, our results are therefore consistent with a cap on external financing of 1.5 the profits of the firm. ${ }^{26}$ That is, even in the presence of what might seem like well functioning credit markets where firms can borrow 1.5x expected profits of the future period, we find that the multiplier effect of an improvement in the working capital cycle can lead to large direct effects on employment.

\footnotetext{
${ }^{25}$ See: http://www.federalreserve.gov/releases/e2/201103/default.htm

${ }^{26} \mathrm{By}$ means of comparison, the mean and median debt-to-ebitda ratios in Compustat as of 2011 are 2.9 and 1.7 , respectively.
} 


\subsection{Spillover Effects}

We next turn to the analysis of spillovers to firms not directly affected by the reform. Our theoretical framework highlights that these firms face an increase in equilibrium wages from the rising labor demand of treated firms, that in turn reduces their demand for labor. To test for the presence and the direction of spillovers, we augment our baseline specification with a measure of total accelerated dollars at the commuting zone level, which is the appropriate level to capture labor market dynamics. ${ }^{27}$ More precisely, we construct the variable Treatment: $C Z$ defined as the average quarterly amount of eligible government contracts to be performed in a given commuting zone between 2009Q1-2011Q1, excluding the focal county $\times$ sector, normalized by aggregate quarterly payrolls in 2011Q1, also excluding the focal county $\times$ sector. Controlling for the treatment at the county-sector level, this measure therefore picks up the intensity of treatment in other county-sectors in a given commuting zone relative to the focal county-sector. The coefficient on this variable is positive if spillovers are positive, and conversely if they are negative. We standardize the county-sector level treatment and the commuting zone level treatment by their respective cross-sectional standard deviations to be able to compare their economic magnitudes. Finally, we augment our baseline specification with several commuting zone level controls including the unemployment rate, the share of small establishments, the average establishment size and the log of total employment and average earnings measured in $2011 \mathrm{Q} 1 .^{28}$

As evidenced in the first row of Table 8, treatment at the county-sector level continues to maintain its significance and economic magnitude. A one standard deviation in Treatment is associated with a $1.3 \%$ increase in payrolls, a $0.9 \%$ increase in employment and a $0.4 \%$ in earnings. The inclusion of Treatment: $C Z$ comes in with a negative and

\footnotetext{
${ }^{27}$ There are a total of 741 commuting zones that cover the entire land area of the US and represent labor market clusters of US counties.

${ }^{28}$ Because we now include a county-level measure as a regressor, we so nor include county fixed effects and include state fixed effects instead.
} 
significant coefficient, implying that a one standard deviation in Treatment at the commuting zone level is associated with a drop by $0.7 \%$ in payrolls and $0.6 \%$ in employment. Little or no effect is found on earnings. ${ }^{29}$ This is consistent with the payment acceleration having substantial crowding out effect on other firms' employment.

In Table 9, we run the same regressions as those in Table 3, but with the inclusion of Treatment: $C Z$ along side the county-sector treatment. Again, it can be seen that there are no pre-trends in payroll growth, either in terms of direct effects and in terms of the crowding out effects. Table 10 runs the same falsification regressions as in Table 4 and shows that crowding out effects are only found in commuting zones with a large exposure to small firm, fixed-price contracts. As with the direct effects, the results in Tables 9 and 10 provide confidence that the effects we are seeing are being driven by the reform, and moreover, are not due to any systematic differences in counties with exposure to either government contracts or small businesses in general.

The fact that non-treated firms grow employment more slowly in more intensely treated commuting zones suggests that there is fluidity across sectors and counties within a defined labor market. However, we would expect the crowding out effects to be felt most strongly within a given sector than across sectors in a given commuting zone. We test this hypothesis in Table 11, where we examine the extent to which the intensity of spillover varies with the level at which we measure treatment, namely, at the commuting zone, the county and the commuting zone-by-sector level. Across the columns of Table 11 we find evidence of negative spillovers whichever way we measure treatment. However, when we include all three together, we see that the effect is captured most strongly by treatment measured at the commuting zone-by-sector level. This suggests that most of the crowding out is happening within sectors, across counties of the same commuting zone. This confirms that firms are most affected by the growth of other firms within their

\footnotetext{
${ }^{29}$ One reason for this result is that the two components of earnings, wages and hours worked, are likely to be affected in different directions by the reform.
} 
own sector.

We then search for direct evidence of employment flows from low to high treatment firms. We use the recently released data on Job-to-Job flows from the Longitudinal Employer-Household Dynamics database to examine the origin and destination Statesectors of people changing jobs. We run regressions of the form

$\% \Delta$ JobFlow $_{o, d}=\beta_{0}+\beta_{1} \cdot$ Treatment $_{o}+\beta_{2} \cdot$ Treatment $_{d}+\beta_{3} \cdot X_{o}+\beta_{4} \cdot X_{d}+\eta_{o}+\omega_{d}+\epsilon_{o, d}$

where $\Delta J_{o b F l o w}, d$ is defined as the percentage growth in average quarterly job flows from State-sectors o to d in the three years before and after the introduction of QuickPay, Treatment $_{o}$ is the treatment for origin State-sector $o$, and Treatment $_{d}$ is the treatment for destination State-sector $d$. As can be seen from Panel A of Table 12, destination sectors exposed to high treatment are more likely to see an inflow and origin sectors exposed to high treatment are less likely to see an outflow of workers. Panel B of Table 12 takes the difference in the treatment between the destination and origin State-sectors and shows that the difference strongly predicts job-flows. Together with the results in Tables 8-11, this is compelling evidence of firms across sectors competing in common local factor markets, leading to crowding out effects when some firms face a reduction in financing constraints.

\subsection{Heterogeneity across Local Labor Markets}

Since our mechanism depends on labor demand among non-treated firms falling due to an increase in equilibrium wages, we should expect the effects to be felt more strongly in counties where there is more labor slack. As can be seen from Figure A.3, there was substantial heterogeneity in the unemployment rates across commuting zones in the time period of our analysis. We therefore segment the commuting zones in our sample into those with relatively high unemployment in 2010 versus those with relatively low unemployment in 2010 and compare the magnitudes in Table 13. In counties where unemployment is 
relatively high, we find that the direct impact of acceleration is felt more strongly and that there is no measured effect in terms of spillovers. On the other hand, in counties where unemployment is already relatively low in 2010, there is substantial crowding out among non-treated firms.

Consistent with the findings in Table 13, when we aggregate the analysis at the commuting zone level, we find in Appendix Table A.10 that the aggregate effects of the reform at the commuting zone level are only observed where unemployment rates are high. By contrast, there is no effect of payment acceleration in commuting zones with lower levels of unemployment. Together, these results provide evidence of the strong interaction effects between financing frictions and local labor market conditions.

Even though we observe negative spillovers of treatment effect on average, this might hide some positive spillover effect through aggregate demand. In the presence of nominal rigidities, if firms in a commuting zone start hiring due to the payment acceleration, this might generate some additional demand for local non-tradable industries. We check whether this is the case by separately estimating the coefficient on the treatment variable measured at the commuting zone level for tradable and non-tradable industries. ${ }^{30}$ As can be seen in Table A.11, the negative spillover effect is largely mitigated for non-tradable industries, which is consistent with the idea that they also benefit from a boost in demand that offset the crowding out effect they experience on their local labor market.

\section{Conclusion}

In this paper we analyze the impact of the Quickpay reform of 2011 and we document two important dimensions through which financing decisions at the firm level impact labor markets. First, we show that a fall in the need to finance payroll and working

\footnotetext{
${ }^{30}$ Non-tradable industries include health care, hospitality, food service, education, retail, and construction.
} 
capital through the production process can have substantial effects on firms' employment decisions, even when financial frictions facing firms are relatively small. This is due to the large multiplier effect that a reduction in working capital can have on cash flows and firm growth. Second, we show that the reduction in financing constraints among some firms can have significant negative spillovers on firms that compete in common factor markets. In some counties in our setting, these spillovers completely negate the positive effects of the reform on firms that benefit from the treatment, although the net effect remains positive in counties with initially higher levels of unemployment. More generally, this crowding out effect has important consequences for policy. The overall effect of a reduction in financing constraints is likely to be significantly smaller when firms compete for talent, particularly in local labor markets where unemployment rates are already low. Our work therefore highlights the strong linkages between capital and labor markets, through the financing frictions and hiring decisions faced by small firms. The degree of financing frictions determine the elasticity of employment with respect to a positive cash flow shock, but the characteristics of the local labor markets also have a bearing on the extent of crowding out and hence the effect such shocks may have on aggregate labor market outcomes. 


\section{References}

Acemoglu, Daron, "Theory, General Equilibrium, and Political Economy in Development Economics," Journal of Economic Perspectives, September 2010, 24 (3), 17-32.

Antras, Pol and C. Fritz Foley, "Poultry in Motion: A Study of International Trade Finance Practices," NBER working paper, May 2011, (17091).

Barrot, Jean-Noel, "Trade credit and industry dynamics: Evidence from trucking firms," The Journal of Finance, 2015.

Basu, Susanto and John G Fernald, "Returns to scale in US production: Estimates and implications," Journal of political economy, 1997, 105 (2), 249-283.

Benmelech, Efraim, Nittai K Bergman, and Amit Seru, "Financing labor," 2011.

Bernanke, Ben S., "Restoring the Flow of Credit to Small Businesses," Federal Reserve Meeting Series: Addressing the Financing Needs of Small Businesses", July 122010 , http://www.federalreserve.gov/newsevents/speech/bernanke20100712a.htm.

Biais, Bruno and Christian Gollier, "Trade Credit and Credit Rationing," Review of Financial Studies, 1997, 10 (4), 903-37.

Blanchard, Olivier Jean, Florencio Lopez de Silanes, and Andrei Shleifer, "What Do Firms Do with Cash Windfalls?," Journal of Financial Economics, 1994, $36(3), 337-360$.

Breza, Emily and Andres Liberman, "Financial contracting and organizational form: Evidence from the regulation of trade credit," Journal of Finance, Forthcoming, 2016.

Burkart, Mike and Tore Ellingsen, "In-Kind Finance: A Theory of Trade Credit," American Economic Review, 2004, 94 (3), 569-590. 
Chaney, Thomas, David Sraer, and David Thesmar, "The Collateral Channel: How Real Estate Shocks Affect Corporate Investment," American Economic Review, 2012, 102 (6), 2381-2409.

_, Zongbo Huang, David Sraer, and David Thesmar, "Aggregate Effects of Collateral Constraints," 2016.

Chodorow-Reich, Gabriel, "The Employment Effects of Credit Market Disruptions: Firm-level Evidence from the 2008-9 Financial Crisis," Quarterly Journal of Economics, 2014, 129 (1), 1-59.

Cohen, Lauren and Christopher Malloy, "Mini west Virginias: Corporations as government dependents," 2014.

Cunat, Vicente, "Trade credit: suppliers as debt collectors and insurance providers," Review of Financial Studies, 2007, 20 (2), 491-527.

Dass, Nishant, Jayant Kale, and Vikram Nanda, "Trade Credit, Relationshipspecific Investment, and Product-market Power," Working paper, 2011.

Demirguc-Kunt, Asli and Vojislav Maksimovic, "Firms as financial intermediaries - evidence from trade credit data," Policy Research Working Paper Series 2696, The World Bank October 2001.

Demiroglu, Cem and Christopher M James, "The information content of bank loan covenants," Review of financial Studies, 2010, 23 (10), 3700-3737.

Dennis, William, "National Small Business Poll: Payroll," NFIB Small Business Poll, 2006, $6(1)$.

Dobridge, Christine L, "Fiscal stimulus and firms: A tale of two recessions," 2016. 
Faulkender, Michael and Mitchell Petersen, "Investment and Capital Constraints: Repatriations Under the American Jobs Creation Act," Review of Financial Studies, 2012, 25 (11), 3351-3388.

Fazzari, Steven M, R Glenn Hubbard, and Bruce C Petersen, "Financing Constraints and Corporate Investment," Brookings Papers on Economic Activity, 1988, $1988(1), 141-206$.

Ferraz, Claudio and Frederico Finan, "Procuring Firm Growth: The Effects of Government Purchases on Firm Dynamics," NBER Working paper, 2015, 21219.

Frank, Murray Z and Vojislav Maksimovic, "Trade Credit, Collateral, and Adverse Selection," Mimeo, University of Maryland, 2005.

Garcia-Appendini, Emilia and Judit Montoriol-Garriga, "Firms as liquidity providers: Evidence from the 2007-2008 financial crisis," Journal of Financial Economics, forthcoming.

Giannetti, M, M Burkart, and T Ellingsen, "What You Sell Is What You Lend? Explaining Trade Credit Contracts," Review of Financial Studies, 2011, 24 (4), 12611298.

Goldman, Jim, "Government as Customer of Last Resort: The Stabilizing Effect of Government Purchases on Firms," 2015.

Greenstone, Michael, Alexandre Mas, and Hoai-Luu Nguyen, "Do credit market shocks affect the real economy? Quasi-experimental evidence from the Great Recession and normaleconomic times," 2014.

Hamermesh, Daniel S, "Labor Demand and the Structure of Adjustment Costs," The American Economic Review, 1989, pp. 674-689. 
- and Gerard A Pfann, "Adjustment costs in factor demand," Journal of Economic Literature, 1996, 34 (3), 1264-1292.

Holmstrom, Bengt and Jean Tirole, "Financial Intermediation, Loanable Funds, and the Real Sector," Quarterly Journal of Economics, August 1997, 112 (3), 663-91.

Horton, John J, "Procurement, Incentives and Bargaining Friction: Evidence from Government Contracts," Available at SSRN 1094622, 2008.

House, Christopher L and Matthew D Shapiro, "Temporary investment tax incentives: theory with evidence from bonus depreciation," The American Economic Review, 2008, 98 (3), 737-768.

Jermann, Urban and Vincenzo Quadrini, "Macroeconomic Effects of Financial Shocks," The American Economic Review, 2012, 102 (1), 238.

Kim, Se-Jik and Hyun Song Shin, "Sustaining Production Chains through Financial Linkages," American Economic Review, May 2012, 102 (3), 402-06.

Klapper, Leora, Luc Laeven, and Raghuram Rajan, "Trade Credit Contracts," Review of Financial Studies, 2012, 25 (3), 838-867.

Lamont, Owen, "Cash Flow and Investment: Evidence from Internal Capital Markets," Journal of Finance, 1997, 52 (1), 83-109.

Liebman, Jeffrey B and Neale Mahoney, "Do expiring budgets lead to wasteful year-end spending? Evidence from federal procurement," 2013.

Mills, Karen, "The State of Small Business Lending: Credit Access During the Recovery and How Technology May Change the Game.," Harvard Business School Working Paper 15-004, 2014. 
Mount, Ian, "When Banks Wont Lend, There Are Alternatives, Though Often Expensive," The New York Times, 2012, Aug 1, 2012 (1).

Murfin, Justin and Ken Njoroge, "The implicit costs of trade credit borrowing by large firms," Review of Financial Studies, 2014, p. hhu051.

Petersen, Mitchell A and Raghuram G Rajan, "Trade credit: theories and evidence," Review of Financial Studies, 1997, 10 (3), 661-691.

Rauh, Joshua D, "Investment and Financing Constraints: Evidence from the Funding of Corporate Pension Plans," Journal of Finance, 2006, 61 (1), 33-71.

Schoefer, Benjamin, "The financial channel of wage rigidity," 2015.

Siemer, Michael, "Firm entry and employment dynamics in the great recession," 2014.

Stiglitz, Joseph E and Andrew Weiss, "Credit Rationing in Markets with Imperfect Information," American Economic Review, June 1981, 71 (3), 393-410.

Whited, Toni M, "Debt, Liquidity Constraints, and Corporate Investment: Evidence from Panel Data," Journal of Finance, 1992, 47 (4), 1425-1460.

Wilner, Benjamin S, "The Exploitation of Relationships in Financial Distress: The Case of Trade Credit," Journal of Finance, 2000, 55 (1), 153-178.

Yellen, Janet, "Interconnectedness and systemic risk: Lessons from the financial crisis and policy implications," Board of Governors of the Federal Reserve System, Washington, $D C, 2013$.

Zwick, Eric and James Mahon, "Tax Policy and Heterogeneous Investment Behavior," 2016. 
Panel A. Total governement contrats

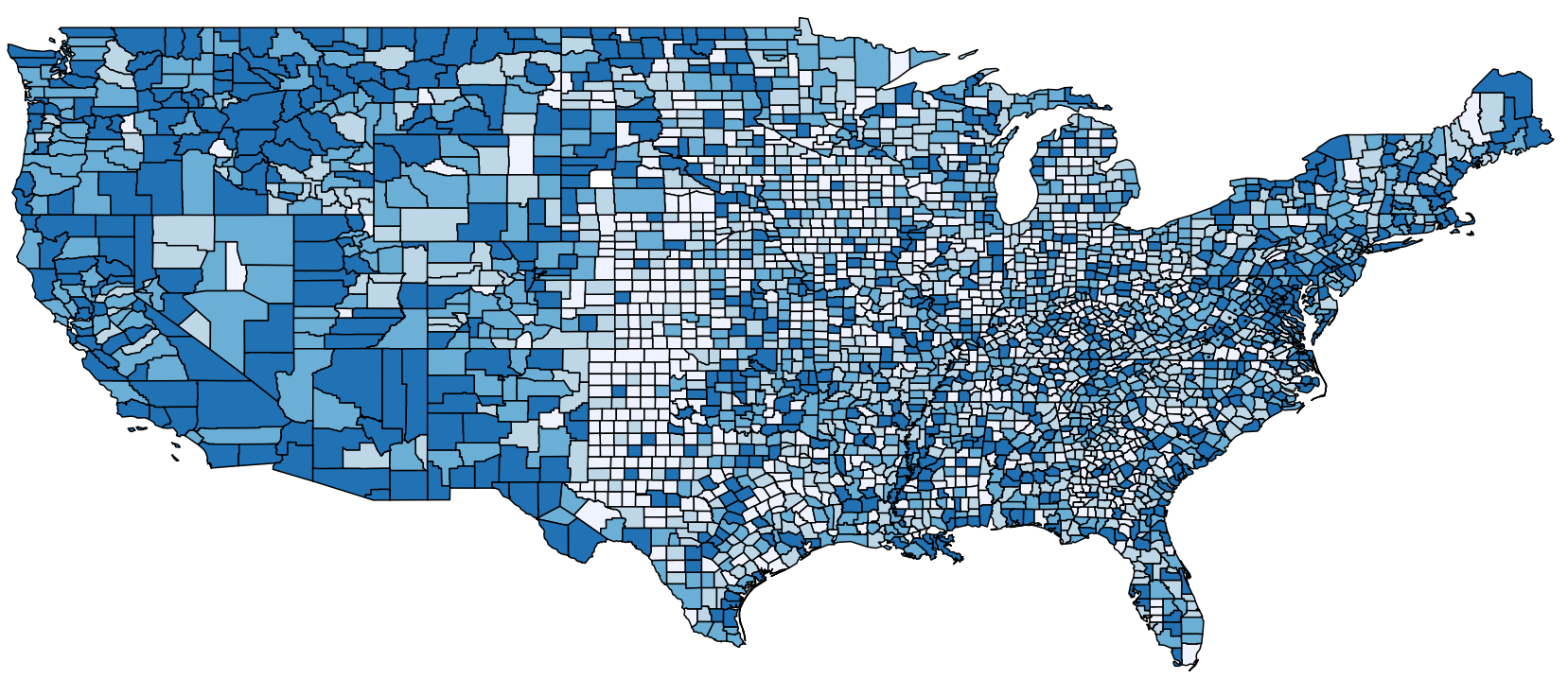

Amount of government contracts over total county payroll (2010-2011)

Panel B. Accelerated governement contracts

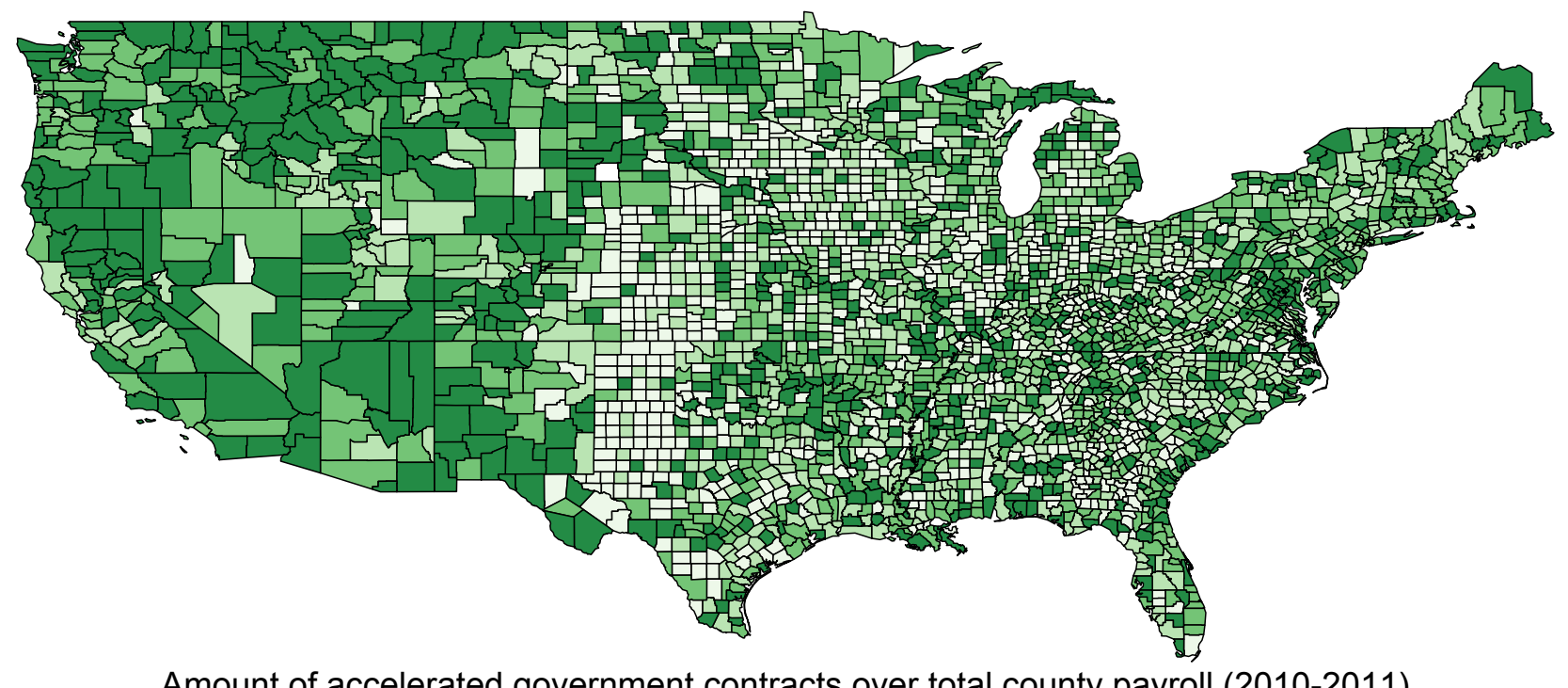

Amount of accelerated government contracts over total county payroll (2010-2011)

Figure 1: Distribution of government contracts across US counties. This figure shows the distribution of total government contracts (Panel A) and government contracts eligible to acceleration (Panel B) aggregated at the county level in the two years prior to the reform, normalized by total county payrolls. Darker shades indicate larger intensity county level exposure. 
Table 1: Summary statistics

Panel A of this table presents summary statistics for the key outcome and control variables, measured at the county $\times$ sector level we consider in our analysis. There are 3120 counties and 18 industries. Treatment is the average quarterly amount of eligible government contracts to be performed in a given county $\times$ sector between 2009Q1-2011Q1, normalized by average quarterly payrolls measured in 2011Q1. Variables of interest include payroll, employment and earnings growth rates between 2011Q1 and 2014Q1. Controls variables include the average quarterly amount of all government contracts to be performed in a given county $\times$ sector between 2009Q1-2011Q1, normalized by average quarterly payrolls during the same period, as well as additional county $\times$ sector controls including the share of small establishment, the average establishment share, 2000Q1 to 2011Q1 average annual employment growth, the correlation of employment growth in a given county $\times$ sector with aggregate employment growth, total employment, total annualized payrolls and average earnings measured in 2011Q1. Panel B presents the distribution of the treatment variable across two-digit sectors.

\begin{tabular}{|c|c|c|c|c|}
\hline \multicolumn{5}{|c|}{ Panel A: Key variables } \\
\hline & Mean & $\mathrm{Sd}$ & $\mathrm{p} 5$ & p95 \\
\hline Treatment & 0.023 & 0.113 & 0.000 & 0.089 \\
\hline Government contracts & 0.067 & 0.322 & 0.000 & 0.251 \\
\hline$\Delta \log$ payroll & 0.146 & 0.391 & -0.369 & 0.698 \\
\hline$\Delta \log$ employment & 0.040 & 0.322 & -0.399 & 0.490 \\
\hline$\Delta \log$ earnings & 0.106 & 0.200 & -0.164 & 0.397 \\
\hline Unemployment rate & 9.464 & 3.026 & 4.600 & 14.500 \\
\hline Corr with US emp growth & 0.120 & 0.275 & -0.331 & 0.579 \\
\hline Average establishment size & 2.219 & 0.870 & 0.916 & 3.726 \\
\hline Share of small establishments & 0.994 & 0.024 & 0.966 & 1.000 \\
\hline Long term employment growth & 0.064 & 0.143 & -0.040 & 0.377 \\
\hline Employment & 2203 & 9728 & 18 & 9009 \\
\hline Annualized earnings ('000) & 32.485 & 19.351 & 11.064 & 66.732 \\
\hline Annualized payroll ('000) & 99809 & 862909 & 368 & 349934 \\
\hline \multicolumn{5}{|c|}{ Panel B: Distribution of treatment across sectors } \\
\hline Accommodation & 0.003 & 0.039 & 0.000 & 0.006 \\
\hline Administrative and support & 0.049 & 0.168 & 0.000 & 0.237 \\
\hline Agriculture & 0.040 & 0.155 & 0.000 & 0.213 \\
\hline Arts & 0.003 & 0.023 & 0.000 & 0.006 \\
\hline Construction & 0.101 & 0.249 & 0.000 & 0.678 \\
\hline Education & 0.023 & 0.117 & 0.000 & 0.095 \\
\hline Finance & 0.001 & 0.016 & 0.000 & 0.000 \\
\hline Health care & 0.003 & 0.023 & 0.000 & 0.009 \\
\hline Information & 0.014 & 0.087 & 0.000 & 0.037 \\
\hline Manufacturing & 0.040 & 0.136 & 0.000 & 0.168 \\
\hline Mining & 0.011 & 0.082 & 0.000 & 0.022 \\
\hline Other services & 0.006 & 0.046 & 0.000 & 0.020 \\
\hline Professional services & 0.032 & 0.107 & 0.000 & 0.146 \\
\hline Real estate & 0.039 & 0.116 & 0.000 & 0.171 \\
\hline Retail & 0.002 & 0.013 & 0.000 & 0.009 \\
\hline Transportation & 0.014 & 0.088 & 0.000 & 0.041 \\
\hline Utilities & 0.008 & 0.070 & 0.000 & 0.014 \\
\hline Wholesale & 0.018 & 0.094 & 0.000 & 0.063 \\
\hline \multirow[t]{2}{*}{ Total } & 0.023 & 0.113 & 0.000 & 0.089 \\
\hline & 36 & & & \\
\hline
\end{tabular}


Table 2: Direct effect of payment acceleration on payrolls

This table presents the results of a difference-in-difference estimation in first-differences. We run OLS regressions at the county $\times$ sector level of the change in log payroll on county $\times$ sector exposure to government contracts that were accelerated following the implementation of the federal payment reform of 2011. Treatment is the average quarterly amount of eligible government contracts to be performed in a given county $\times$ sector between 2009Q1-2011Q1, normalized by quarterly payrolls in 2011Q1. Control variables include the average quarterly amount of all government contracts to be performed in a given county $\times$ sector between 2009Q1-2011Q1, normalized by quarterly payrolls in 2011Q1, as well as additional county $\times$ sector controls including the share of small establishment, the log average establishment size, 2000Q1 to 2011Q1 average annual employment growth, the correlation of employment growth with aggregate employment growth, the log of total employment and the log average earnings. There are 3120 counties and 18 industries. Panel A presents the baseline estimation. In Panel B, the treatment variable is normalized by its cross-sectional standard deviation. Standard errors presented in parentheses are clustered at the State-level. *, **, and ${ }^{* * *}$ denote significance at the $10 \%, 5 \%$, and $1 \%$, respectively.

\begin{tabular}{|c|c|c|c|c|c|}
\hline \multirow[b]{3}{*}{ Treatment } & \multicolumn{5}{|c|}{$\Delta$ Log payroll (2011Q1-2014Q1) } \\
\hline & \multicolumn{5}{|c|}{ Panel A: Baseline } \\
\hline & $\begin{array}{c}0.192^{* * *} \\
(0.038)\end{array}$ & $\begin{array}{c}0.128^{* * *} \\
(0.036)\end{array}$ & $\begin{array}{c}0.114^{* * *} \\
(0.036)\end{array}$ & $\begin{array}{c}0.132^{* * *} \\
(0.037)\end{array}$ & $\begin{array}{c}0.097^{* * *} \\
(0.036)\end{array}$ \\
\hline County $\times$ sector controls & No & Yes & Yes & Yes & Yes \\
\hline Sector FE & No & No & Yes & No & Yes \\
\hline County FE & No & No & No & Yes & Yes \\
\hline Observations & 45333 & 45333 & 45333 & 45333 & 45333 \\
\hline \multirow[t]{2}{*}{$R^{2}$} & 0.003 & 0.045 & 0.059 & 0.147 & 0.166 \\
\hline & \multicolumn{5}{|c|}{ Panel B: Standardized treatment } \\
\hline Treatment (std) & $\begin{array}{c}0.022^{* * *} \\
(0.004)\end{array}$ & $\begin{array}{c}0.015^{* * *} \\
(0.004)\end{array}$ & $\begin{array}{c}0.013^{* * *} \\
(0.004)\end{array}$ & $\begin{array}{c}0.015^{* * *} \\
(0.004)\end{array}$ & $\begin{array}{c}0.011^{* * *} \\
(0.004)\end{array}$ \\
\hline County $\times$ sector controls & No & Yes & Yes & Yes & Yes \\
\hline Sector FE & No & No & Yes & No & Yes \\
\hline County FE & No & No & No & Yes & Yes \\
\hline Observations & 45333 & 45333 & 45333 & 45333 & 45333 \\
\hline$R^{2}$ & 0.003 & 0.045 & 0.059 & 0.147 & 0.166 \\
\hline
\end{tabular}


Table 3: Direct effect of payment acceleration: dynamics

This table presents the results of a difference-in-difference estimation in first-differences. We run OLS regressions at the county $\times$ sector level of the change in log payroll on county $\times$ sector exposure to government contracts that were accelerated following the implementation of the federal payment reform of 2011. Treatment is the average quarterly amount of eligible government contracts to be performed in a given county $\times$ sector between 2009Q1-2011Q1, normalized by quarterly payrolls in 2011Q1. Control variables include the average quarterly amount of all government contracts to be performed in a given county $\times$ sector between 2009Q1-2011Q1, normalized by quarterly payrolls in 2011Q1, as well as additional county $\times$ sector controls including the share of small establishment, the log average establishment size, 2000Q1 to 2011Q1 average annual employment growth, the correlation of employment growth with aggregate employment growth, the log of total employment and the log average earnings. There are 3120 counties and 18 industries. Standard errors presented in parentheses are clustered at the State-level. *, **, and ${ }^{* * *}$ denote significance at the $10 \%, 5 \%$, and $1 \%$, respectively.

\begin{tabular}{lccccc}
\hline \hline & \multicolumn{5}{c}{$\Delta$ Log payroll (relative to 2011Q1) } \\
\cline { 2 - 6 } & {$[\mathrm{t}-2, \mathrm{t}]$} & {$[\mathrm{t}-1, \mathrm{t}]$} & {$[\mathrm{t}, \mathrm{t}+1]$} & {$[\mathrm{t}, \mathrm{t}+2]$} & {$[\mathrm{t}, \mathrm{t}+3]$} \\
& & & & & \\
Treatment & -0.014 & -0.035 & 0.046 & $0.079^{* *}$ & $0.097^{* * *}$ \\
& $(0.024)$ & $(0.031)$ & $(0.028)$ & $(0.030)$ & $(0.036)$ \\
County $\times$ sector controls & Yes & Yes & Yes & Yes & Yes \\
Sector FE & Yes & Yes & Yes & Yes & Yes \\
County FE & Yes & Yes & Yes & Yes & Yes \\
& & & & & \\
Observations & 45172 & 45159 & 45201 & 45201 & 45333 \\
$R^{2}$ & 0.576 & 0.320 & 0.127 & 0.146 & 0.166 \\
& & & & & \\
\hline \hline
\end{tabular}


Table 4: Direct effect of payment acceleration: falsification tests

This table presents the results of a difference-in-difference estimation in first-differences. We run OLS regressions at the county $\times$ sector level of the change in log payroll on county $\times$ sector exposure to government contracts normalized by quarterly payrolls in 2011Q1. Small and Large refer to contracts awarded to small and large business respectively. Fixed-price and Cost-plus contracts refer to fixed-price and costplus contracts, respectively. Control variables include the average quarterly amount of all government contracts to be performed in a given county $\times$ sector between 2009Q1-2011Q1, normalized by quarterly payrolls in 2011Q1, as well as additional county $\times$ sector controls including the share of small establishment, the log average establishment size, 2000Q1 to 2011Q1 average annual employment growth, the correlation of employment growth with aggregate employment growth, the log of total employment and the log average earnings. There are 3120 counties and 18 industries. Standard errors presented in parentheses are clustered at the State-level. *,**, and ${ }^{* * *}$ denote significance at the $10 \%, 5 \%$, and $1 \%$, respectively.

\begin{tabular}{|c|c|c|c|c|c|}
\hline \multirow[b]{2}{*}{ Small and fixed-price } & \multicolumn{5}{|c|}{$\Delta$ Log payroll (2011Q1-2014Q1) } \\
\hline & $\begin{array}{c}0.186^{* * *} \\
(0.033)\end{array}$ & $\begin{array}{c}0.124^{* * *} \\
(0.031)\end{array}$ & $\begin{array}{c}0.106^{* * *} \\
(0.032)\end{array}$ & $\begin{array}{c}0.133^{* * *} \\
(0.033)\end{array}$ & $\begin{array}{r}0.091^{* * *} \\
(0.033)\end{array}$ \\
\hline Large and fixed-price & $\begin{array}{l}-0.009 \\
(0.013)\end{array}$ & $\begin{array}{l}-0.010 \\
(0.012)\end{array}$ & $\begin{array}{c}-0.010 \\
(0.013)\end{array}$ & $\begin{array}{l}-0.010 \\
(0.012)\end{array}$ & $\begin{array}{l}-0.018 \\
(0.012)\end{array}$ \\
\hline Small and cost-plus & $\begin{array}{l}-0.124 \\
(0.119)\end{array}$ & $\begin{array}{l}-0.102 \\
(0.119)\end{array}$ & $\begin{array}{l}-0.127 \\
(0.116)\end{array}$ & $\begin{array}{c}0.004 \\
(0.123)\end{array}$ & $\begin{array}{l}-0.044 \\
(0.120)\end{array}$ \\
\hline Large and cost-plus & $\begin{array}{l}-0.008 \\
(0.016)\end{array}$ & $\begin{array}{c}0.004 \\
(0.016)\end{array}$ & $\begin{array}{l}-0.002 \\
(0.016)\end{array}$ & $\begin{array}{c}0.016 \\
(0.017)\end{array}$ & $\begin{array}{c}0.014 \\
(0.017)\end{array}$ \\
\hline County $\times$ sector controls & No & Yes & Yes & Yes & Yes \\
\hline Sector FE & No & No & Yes & No & Yes \\
\hline County FE & No & No & No & Yes & Yes \\
\hline Observations & 45333 & 45333 & 45333 & 45333 & 45333 \\
\hline$R^{2}$ & 0.003 & 0.045 & 0.059 & 0.147 & 0.166 \\
\hline
\end{tabular}


Table 5: Direct effect of payment acceleration: heterogeneous treatment effects This table presents the results of a difference-in-difference estimation in first-differences. We run OLS regressions at the county $\times$ sector level of the change in $\log$ payroll on county $\times$ sector exposure to government contracts that were accelerated following the implementation of the federal payment reform of 2011. Treatment is the average quarterly amount of eligible government contracts to be performed in a given county $\times$ sector between 2009Q1-2011Q1, normalized by quarterly payrolls in 2011Q1. The treatment variable is interacted successively with a dummy for high payroll/sales sectors (based on BEA industry accounts), high receivables/assets sectors (based on Compustat), high pledgeability (fixed assets/assets based on Compustat), and high small business loans per establishments (based on Community Reinvestment Act and County Business Patterns data). Control variables include the average quarterly amount of all government contracts to be performed in a given county $\times$ sector between 2009Q1-2011Q1, normalized by quarterly payrolls in 2011Q1, as well as additional county $\times$ sector controls including the share of small establishment, the log average establishment size, 2000Q1 to 2011Q1 average annual employment growth, the correlation of employment growth with aggregate employment growth, the log of total employment and the log average earnings. There are 3120 counties and 18 industries. Standard errors presented in parentheses are clustered at the State-level. * ${ }^{* *}$, and ${ }^{* * *}$ denote significance at the $10 \%, 5 \%$, and $1 \%$, respectively.

\begin{tabular}{|c|c|c|c|c|}
\hline & \multicolumn{4}{|c|}{$\Delta$ Log payroll (2011Q1-2014Q1) } \\
\hline & \multicolumn{2}{|c|}{ Treatment intensity } & \multicolumn{2}{|c|}{ Access to external finance } \\
\hline & $\begin{array}{l}\text { Sector mean } \\
\text { payroll/sales }\end{array}$ & $\begin{array}{l}\text { Sector mean } \\
\text { receivables/assets }\end{array}$ & $\begin{array}{l}\text { Sector mean } \\
\text { pledgeability }\end{array}$ & $\begin{array}{l}\text { Small bus. loans } \\
\text { per establishment }\end{array}$ \\
\hline Treatment $\times$ high & $\begin{array}{l}0.143^{* *} \\
(0.057)\end{array}$ & $\begin{array}{c}0.119^{* * *} \\
(0.043)\end{array}$ & $\begin{array}{c}0.044 \\
(0.049)\end{array}$ & $\begin{array}{l}0.044 \\
(0.044)\end{array}$ \\
\hline Treatment $\times$ low & $\begin{array}{l}0.040 \\
(0.035)\end{array}$ & $\begin{array}{c}0.043 \\
(0.057)\end{array}$ & $\begin{array}{c}0.122^{* * *} \\
(0.046)\end{array}$ & $\begin{array}{l}0.142^{* *} \\
(0.061)\end{array}$ \\
\hline County $\times$ sector controls & Yes & Yes & Yes & Yes \\
\hline Sector FE & Yes & Yes & Yes & Yes \\
\hline County FE & Yes & Yes & Yes & Yes \\
\hline $\begin{array}{l}\text { Observations } \\
R^{2}\end{array}$ & 45333 & 42350 & 42350 & 45333 \\
\hline$R^{2}$ & 0.166 & 0.173 & 0.173 & 0.166 \\
\hline
\end{tabular}


Table 6: Direct effect of payment acceleration: employment and earnings This table presents the results of a difference-in-difference estimation in first-differences. We run OLS regressions at the county $\times$ sector level of the change in log employment (Panel A) and log average earnings (Panel B) on county $\times$ sector exposure to government contracts that were accelerated following the implementation of the federal payment reform of 2011. Treatment is the average quarterly amount of eligible government contracts to be performed in a given county $\times$ sector between 2009Q1-2011Q1, normalized by quarterly payrolls in 2011Q1. Control variables include the average quarterly amount of all government contracts to be performed in a given county $\times$ sector between 2009Q1-2011Q1, normalized by quarterly payrolls in 2011Q1, as well as additional county $\times$ sector controls including the share of small establishment, the log average establishment size, 2000Q1 to 2011Q1 average annual employment growth, the correlation of employment growth with aggregate employment growth, the log of total employment and the log average earnings. There are 3120 counties and 18 industries. Standard errors presented in parentheses are clustered at the State-level. * ${ }^{* *}$, and ${ }^{* * *}$ denote significance at the $10 \%, 5 \%$, and $1 \%$, respectively.

\begin{tabular}{|c|c|c|c|c|c|}
\hline \multirow[b]{2}{*}{ Treatment } & \multicolumn{5}{|c|}{ Panel A: $\Delta$ log employment (2011Q1-2014Q1) } \\
\hline & $\begin{array}{c}0.119^{* * *} \\
(0.029)\end{array}$ & $\begin{array}{c}0.086^{* * *} \\
(0.029)\end{array}$ & $\begin{array}{c}0.075^{* * *} \\
(0.027)\end{array}$ & $\begin{array}{c}0.090^{* * *} \\
(0.030)\end{array}$ & $\begin{array}{c}0.062^{* *} \\
(0.029)\end{array}$ \\
\hline County $\times$ sector controls & No & Yes & Yes & Yes & Yes \\
\hline Sector FE & No & No & Yes & No & Yes \\
\hline County FE & No & No & No & Yes & Yes \\
\hline Observations & 45333 & 45333 & 45333 & 45333 & 45333 \\
\hline$R^{2}$ & 0.002 & 0.037 & 0.056 & 0.132 & 0.157 \\
\hline \multicolumn{6}{|l|}{ hline } \\
\hline & \multicolumn{5}{|c|}{ Panel B: $\Delta$ log earnings (2011Q1-2014Q1) } \\
\hline Treatment & $\begin{array}{c}0.073^{* * *} \\
(0.019)\end{array}$ & $\begin{array}{c}0.042^{* *} \\
(0.017)\end{array}$ & $\begin{array}{c}0.039^{* *} \\
(0.017)\end{array}$ & $\begin{array}{c}0.042^{* *} \\
(0.017)\end{array}$ & $\begin{array}{l}0.035^{* *} \\
(0.017)\end{array}$ \\
\hline County $\times$ sector controls & No & Yes & Yes & Yes & Yes \\
\hline Sector FE & No & No & Yes & No & Yes \\
\hline County FE & No & No & No & Yes & Yes \\
\hline Observations & 45333 & 45333 & 45333 & 45333 & 45333 \\
\hline$R^{2}$ & 0.001 & 0.083 & 0.142 & 0.162 & 0.221 \\
\hline
\end{tabular}


Table 7: Direct effect of payment acceleration: implied financing frictions This table presents the values for employment growth implied by our theoretical framework presented in section 2 as a function of the pledgeability constraint $\xi$. We also present the corresponding reduced form coefficient, where we divide the model prediction by 3 to reflect the fact that our treatment variable is scaled by payroll rather than sales.

\begin{tabular}{|c|c|c|c|c|c|c|c|}
\hline \multirow[b]{2}{*}{$\xi$} & \multicolumn{7}{|c|}{ Predicted employment growth as a function of $\xi$} \\
\hline & 0.70 & 0.85 & 1.00 & 1.15 & 1.30 & 1.45 & 1.60 \\
\hline Implied $\Delta L_{t}^{*}-1$ & 0.41 & 0.34 & 0.29 & 0.25 & 0.22 & 0.20 & 0.18 \\
\hline Corresponding reduced form coefficient & 0.138 & 0.113 & 0.96 & 0.083 & 0.073 & 0.066 & 0.060 \\
\hline
\end{tabular}


Table 8: Spillover effect of payment acceleration: baseline

This table presents the results of a difference-in-difference estimation in first-differences. We run OLS regressions at the county $\times$ sector level of the change in log payroll, log employment and log earnings on county $\times$ sector exposure to government contracts that were accelerated following the implementation of the federal payment reform of 2011. Treatment is the average quarterly amount of eligible government contracts to be performed in a given county $\times$ sector between 2009Q1-2011Q1, normalized by quarterly payrolls in 2011Q1. Treatment: $C Z$ is the same variable, measured at the commuting zone level rather than the county $\times$ sector level, and excluding the focal county $\times$ sector. Treatment and Treatment: $C Z$ are normalized by their cross-sectional standard deviation. County $\times$ sector control variables include the average quarterly amount of all government contracts to be performed in a given county $\times$ sector between 2009Q1-2011Q1, normalized by quarterly payrolls in 2011Q1, as well as additional county $\times$ sector controls including the share of small establishment, the log average establishment size, 2000Q1 to 2011Q1 average annual employment growth, the correlation of employment growth with aggregate employment growth, the log of total employment and the log average earnings. CZ controls include the unemployment rate, the share of small establishments, the log average establishment size, log total employment and log average earnings in 2011Q1. There are 3120 counties and 18 industries. Standard errors presented in parentheses are clustered at the State-level. *, ${ }^{* *}$, and ${ }^{* * *}$ denote significance at the $10 \%, 5 \%$, and $1 \%$, respectively.

\begin{tabular}{|c|c|c|c|c|c|c|}
\hline \multirow[b]{2}{*}{ Treatment } & \multicolumn{2}{|c|}{$\Delta$ log payroll } & \multicolumn{2}{|c|}{$\Delta$ log employment } & \multicolumn{2}{|c|}{$\Delta \log$ earnings } \\
\hline & $\begin{array}{c}0.015^{* * *} \\
(0.004)\end{array}$ & $\begin{array}{c}0.013^{* * *} \\
(0.004)\end{array}$ & $\begin{array}{c}0.010^{* * *} \\
(0.003)\end{array}$ & $\begin{array}{c}0.009^{* * *} \\
(0.003)\end{array}$ & $\begin{array}{c}0.005^{* *} \\
(0.002)\end{array}$ & $\begin{array}{l}0.004^{* *} \\
(0.002)\end{array}$ \\
\hline Treatment: CZ & $\begin{array}{c}-0.009^{* *} \\
(0.004)\end{array}$ & $\begin{array}{c}-0.007^{*} \\
(0.004)\end{array}$ & $\begin{array}{c}-0.006^{*} \\
(0.003)\end{array}$ & $\begin{array}{c}-0.006^{* *} \\
(0.003)\end{array}$ & $\begin{array}{l}-0.003^{*} \\
(0.002)\end{array}$ & $\begin{array}{l}-0.001 \\
(0.002)\end{array}$ \\
\hline County $\times$ sector controls & Yes & Yes & Yes & Yes & Yes & Yes \\
\hline CZ controls & Yes & Yes & Yes & Yes & Yes & Yes \\
\hline Sector FE & No & Yes & No & Yes & No & Yes \\
\hline State FE & Yes & Yes & Yes & Yes & Yes & Yes \\
\hline Observations & 45318 & 45318 & 45318 & 45318 & 45318 & 45318 \\
\hline$R^{2}$ & 0.060 & 0.076 & 0.048 & 0.068 & 0.093 & 0.154 \\
\hline
\end{tabular}


Table 9: Spillover effect of payment acceleration: dynamics

This table presents the results of a difference-in-difference estimation in first-differences. We run OLS regressions at the county $\times$ sector level of the change in log employment on county $\times$ sector exposure to government contracts that were accelerated following the implementation of the federal payment reform of 2011. Treatment is the average quarterly amount of eligible government contracts to be performed in a given county $\times$ sector between 2009Q1-2011Q1, normalized by quarterly payrolls in 2011Q1. Treatment: $C Z$ is the same variable, measured at the commuting zone level rather than the county $\times$ sector level, and excluding the focal county $\times$ sector. Treatment and Treatment: $C Z$ are normalized by their crosssectional standard deviation. County $\times$ sector control variables include the average quarterly amount of all government contracts to be performed in a given county $\times$ sector between 2009Q1-2011Q1, normalized by quarterly payrolls in 2011Q1, as well as additional county $\times$ sector controls including the share of small establishment, the log average establishment size, 2000Q1 to 2011Q1 average annual employment growth, the correlation of employment growth with aggregate employment growth, the log of total employment and the log average earnings. CZ controls include the unemployment rate, the share of small establishments, the log average establishment size, log total employment and log average earnings in 2011Q1. There are 3120 counties and 18 industries. Standard errors presented in parentheses are clustered at the State-level. $*,{ }^{* *}$, and ${ }^{* * *}$ denote significance at the $10 \%, 5 \%$, and $1 \%$, respectively.

\begin{tabular}{lccccc}
\hline \hline & \multicolumn{5}{c}{$\Delta$ log employment (relative to 2011Q1) } \\
\cline { 2 - 6 } & {$[\mathrm{t}-2, \mathrm{t}]$} & {$[\mathrm{t}-1, \mathrm{t}]$} & {$[\mathrm{t}, \mathrm{t}+1]$} & {$[\mathrm{t}, \mathrm{t}+2]$} & {$[\mathrm{t}, \mathrm{t}+3]$} \\
& & & & & \\
Treatment & -0.001 & -0.002 & $0.003^{*}$ & $0.008^{* * *}$ & $0.009^{* * *}$ \\
& $(0.002)$ & $(0.002)$ & $(0.002)$ & $(0.003)$ & $(0.003)$ \\
Treatment: CZ & 0.000 & -0.000 & -0.003 & -0.005 & $-0.006^{* *}$ \\
& $(0.001)$ & $(0.001)$ & $(0.002)$ & $(0.003)$ & $(0.003)$ \\
& & & & & \\
County $\times$ sector controls & Yes & Yes & Yes & Yes & Yes \\
CZ controls & Yes & Yes & Yes & Yes & Yes \\
Sector FE & Yes & Yes & Yes & Yes & Yes \\
State FE & Yes & Yes & Yes & Yes & Yes \\
& & & & & \\
Observations & 45157 & 45144 & 45186 & 45186 & 45318 \\
$R^{2}$ & 0.549 & 0.271 & 0.039 & 0.054 & 0.068 \\
& & & & & \\
\hline \hline
\end{tabular}


Table 10: Spillover effect of payment acceleration: falsification tests

This table presents the results of a difference-in-difference estimation in first-differences. We run OLS regressions at the county $\times$ sector level of the change in log employment on commuting zone exposure to government contracts normalized by quarterly payrolls in 2011Q1. Small and Large refer to contracts awarded to small and large business respectively. Fixed-price and Cost-plus contracts refer to fixed-price and cost-plus contracts, respectively. All four variables are standardized by their cross-sectional standard deviation. County $\times$ sector control variables include the average quarterly amount of all government contracts to be performed in a given county $\times$ sector between 2009Q1-2011Q1, normalized by quarterly payrolls in 2011Q1, as well as additional county $\times$ sector controls including the share of small establishment, the log average establishment size, 2000Q1 to 2011Q1 average annual employment growth, the correlation of employment growth with aggregate employment growth, the log of total employment and the $\log$ average earnings. CZ controls include the unemployment rate, the share of small establishments, the log average establishment size, log total employment and log average earnings in 2011Q1. There are 3120 counties and 18 industries. Standard errors presented in parentheses are clustered at the State-level. *, ${ }^{* *}$, and ${ }^{* * *}$ denote significance at the $10 \%, 5 \%$, and $1 \%$, respectively.

\begin{tabular}{lccccc}
\hline \hline & \multicolumn{5}{c}{$\Delta$ log employment $(2011 \mathrm{Q} 1-2014 \mathrm{Q} 1)$} \\
\cline { 2 - 6 } & & & & & \\
Small and fixed-price: CZ & $-0.011^{* * *}$ & $-0.007^{* *}$ & $-0.011^{* * *}$ & $-0.007^{* *}$ & $-0.007^{* *}$ \\
& $(0.003)$ & $(0.003)$ & $(0.003)$ & $(0.003)$ & $(0.003)$ \\
Large and fixed-price: CZ & 0.003 & 0.000 & 0.003 & 0.000 & 0.001 \\
& $(0.003)$ & $(0.003)$ & $(0.003)$ & $(0.003)$ & $(0.002)$ \\
Small and cost-plus: CZ & 0.002 & 0.001 & 0.002 & 0.001 & 0.001 \\
& $(0.002)$ & $(0.002)$ & $(0.002)$ & $(0.002)$ & $(0.002)$ \\
Large and cost-plus: CZ & 0.002 & -0.002 & 0.002 & -0.002 & -0.002 \\
& $(0.002)$ & $(0.002)$ & $(0.002)$ & $(0.002)$ & $(0.002)$ \\
& & & & & \\
County $\times$ sector controls & No & Yes & No & Yes & Yes \\
CZ controls & No & Yes & No & Yes & Yes \\
Sector FE & No & No & Yes & No & Yes \\
State FE & Yes & Yes & Yes & Yes & Yes \\
& & & & & \\
Observations & 45333 & 45318 & 45333 & 45318 & 45318 \\
$R^{2}$ & 0.010 & 0.048 & 0.025 & 0.048 & 0.068 \\
& & & & & \\
\hline \hline
\end{tabular}


Table 11: Spillover effect of payment acceleration: heterogeneity

This table presents the results of a difference-in-difference estimation in first-differences. We run OLS regressions at the county $\times$ sector level of the change in log payroll on county $\times$ sector exposure to government contracts that were accelerated following the implementation of the federal payment reform of 2011. Treatment is the average quarterly amount of eligible government contracts to be performed in a given county $\times$ sector between 2009Q1-2011Q1, normalized by quarterly payrolls in 2011Q1. Treatment: $C Z$, Treatment: county, and Treatment: $C Z^{*}$ Sector are the same variable, measured at the commuting zone, county and commuting zone and sector level rather than the county $\times$ sector level, and excluding the focal county $\times$ sector. All treatment variables are normalized by their cross-sectional standard deviation. County $\times$ sector control variables include the average quarterly amount of all government contracts to be performed in a given county $\times$ sector between 2009Q1-2011Q1, normalized by quarterly payrolls in 2011Q1, as well as additional county $\times$ sector controls including the share of small establishment, the $\log$ average establishment size, 2000Q1 to 2011Q1 average annual employment growth, the correlation of employment growth with aggregate employment growth, the log of total employment and the log average earnings. CZ controls include the unemployment rate, the share of small establishments, the log average establishment size, log total employment and log average earnings in 2011Q1. There are 3120 counties and 18 industries.Standard errors presented in parentheses are clustered at the State-level. *, **, and *** denote significance at the $10 \%, 5 \%$, and $1 \%$, respectively.

\begin{tabular}{|c|c|c|c|c|}
\hline \multirow{2}{*}{\multicolumn{5}{|c|}{ Treatment variables are standardized by their sample standard deviation }} \\
\hline & & & & \\
\hline Treatment & $\begin{array}{c}0.009^{* * *} \\
(0.003)\end{array}$ & $\begin{array}{c}0.009^{* * *} \\
(0.003)\end{array}$ & $\begin{array}{c}0.009^{* * *} \\
(0.003)\end{array}$ & $\begin{array}{c}0.009^{* * *} \\
(0.003)\end{array}$ \\
\hline Treatment: CZ & $\begin{array}{c}-0.006^{* *} \\
(0.003)\end{array}$ & & & $\begin{array}{l}-0.003 \\
(0.004)\end{array}$ \\
\hline Treatment: county & & $\begin{array}{c}-0.004^{*} \\
(0.002)\end{array}$ & & $\begin{array}{l}-0.003 \\
(0.002)\end{array}$ \\
\hline Treatment: CZ*Sector & & & $\begin{array}{c}-0.006^{* *} \\
(0.002)\end{array}$ & $\begin{array}{c}-0.005^{* *} \\
(0.002)\end{array}$ \\
\hline County $\times$ sector controls & Yes & Yes & Yes & Yes \\
\hline CZ controls & Yes & Yes & Yes & Yes \\
\hline Sector FE & Yes & Yes & Yes & Yes \\
\hline State FE & Yes & Yes & Yes & Yes \\
\hline Observations & 45318 & 45314 & 44043 & 44039 \\
\hline$R^{2}$ & 0.068 & 0.068 & 0.070 & 0.070 \\
\hline
\end{tabular}


Table 12: Spillover effect of payment acceleration: Job-to-job flows This table presents the results of a difference-in-difference estimation in first-differences. We run OLS regressions at the origin State-sector $\times$ destination State-sector of the percentage growth in average quarterly job flows between the three year prior to the reform and three subsequent years. Treatment is the average quarterly amount of eligible government contracts to be performed in a given Statexsector between 2009Q1-2011Q1, normalized by average quarterly payrolls in 2011Q1. In Panel A, both treatment variables for the origin and destination sectors enter the regressions separately, while we use the difference between the two in Panel B. Control variables include the average quarterly amount of all government contracts to be performed in a given State×sector between 2009Q1-2011Q1, normalized by quarterly payrolls in 2011Q1, as well as additional State×sector controls including the share of small establishment, the log average establishment size, 2000Q1 to 2011Q1 average annual employment growth, the correlation of employment growth with aggregate employment growth, the log of total employment and the log average earnings. Standard errors presented in parentheses are clustered at the State-level. $*, * *$, and ${ }^{* * *}$ denote significance at the $10 \%, 5 \%$, and $1 \%$, respectively.

\begin{tabular}{|c|c|c|c|c|c|}
\hline \multirow[b]{2}{*}{ Treatment, destination } & \multicolumn{5}{|c|}{ Growth in average quarterly job flows } \\
\hline & $\begin{array}{l}0.251 \\
(0.215)\end{array}$ & $\begin{array}{l}0.450^{* *} \\
(0.218)\end{array}$ & $\begin{array}{l}0.364^{*} \\
(0.185)\end{array}$ & $\begin{array}{l}0.451^{* *} \\
(0.217)\end{array}$ & $\begin{array}{l}0.367^{*} \\
(0.185)\end{array}$ \\
\hline Treatment, origin & $\begin{array}{c}-0.741^{* * *} \\
(0.094)\end{array}$ & $\begin{array}{l}-0.108 \\
(0.097)\end{array}$ & $\begin{array}{l}-0.092 \\
(0.107)\end{array}$ & $\begin{array}{l}-0.075 \\
(0.089)\end{array}$ & $\begin{array}{l}-0.109 \\
(0.100)\end{array}$ \\
\hline \multirow[t]{2}{*}{$R^{2}$} & $\begin{array}{l}341947 \\
0.005\end{array}$ & $\begin{array}{c}331733 \\
0.011\end{array}$ & $\begin{array}{c}331733 \\
0.013\end{array}$ & $\begin{array}{c}331733 \\
0.011\end{array}$ & $\begin{array}{c}331733 \\
0.014\end{array}$ \\
\hline & \multicolumn{5}{|c|}{ Growth in average quarterly job flows } \\
\hline Difference in treatment & $\begin{array}{c}0.515^{* * *} \\
(0.117)\end{array}$ & $\begin{array}{l}0.267^{* *} \\
(0.113)\end{array}$ & $\begin{array}{l}0.217^{* *} \\
(0.107)\end{array}$ & $\begin{array}{l}0.267^{* *} \\
(0.113)\end{array}$ & $\begin{array}{l}0.241^{* *} \\
(0.106)\end{array}$ \\
\hline $\begin{array}{l}\text { Observations } \\
R^{2}\end{array}$ & $\begin{array}{c}341947 \\
0.005\end{array}$ & $\begin{array}{c}331733 \\
0.011\end{array}$ & $\begin{array}{c}331733 \\
0.013\end{array}$ & $\begin{array}{c}331733 \\
0.011\end{array}$ & $\begin{array}{c}331733 \\
0.014\end{array}$ \\
\hline $\begin{array}{l}\text { Controls (origin State-sector) } \\
\text { Controls (destination State-sector) } \\
\text { Origin sector FE } \\
\text { Destination sector FE } \\
\text { Destination State FE } \\
\text { Origin State FE }\end{array}$ & $\begin{array}{l}\text { No } \\
\text { No } \\
\text { No } \\
\text { No } \\
\text { Yes } \\
\text { No }\end{array}$ & $\begin{array}{l}\text { Yes } \\
\text { Yes } \\
\text { No } \\
\text { No } \\
\text { Yes } \\
\text { No }\end{array}$ & $\begin{array}{l}\text { Yes } \\
\text { Yes } \\
\text { Yes } \\
\text { Yes } \\
\text { Yes } \\
\text { No }\end{array}$ & $\begin{array}{l}\text { Yes } \\
\text { Yes } \\
\text { No } \\
\text { No } \\
\text { Yes } \\
\text { Yes }\end{array}$ & $\begin{array}{l}\text { Yes } \\
\text { Yes } \\
\text { Yes } \\
\text { Yes } \\
\text { Yes } \\
\text { Yes }\end{array}$ \\
\hline
\end{tabular}


Table 13: Spillover effect of payment acceleration: labor market tightness This table presents the results of a difference-in-difference estimation in first-differences. We run OLS regressions at the county $\times$ sector level of the change in log payroll on county $\times$ sector exposure to government contracts that were accelerated following the implementation of the federal payment reform of 2011. Treatment is the average quarterly amount of eligible government contracts to be performed in a given county $\times$ sector between 2009Q1-2011Q1, normalized by quarterly payrolls in 2011Q1. Treatment: $C Z$ is the same variable, measured at the commuting zone level rather than the county $\times$ sector level, and excluding the focal county $\times$ sector. Treatment and Treatment: $C Z$ are normalized by their crosssectional standard deviation. County $\times$ sector control variables include the average quarterly amount of all government contracts to be performed in a given county $\times$ sector between 2009Q1-2011Q1, normalized by quarterly payrolls in 2011Q1, as well as additional county $\times$ sector controls including the share of small establishment, the log average establishment size, 2000Q1 to 2011Q1 average annual employment growth, the correlation of employment growth with aggregate employment growth, the log of total employment and the log average earnings. CZ controls include the unemployment rate, the share of small establishments, the log average establishment size, log total employment and log average earnings in 2011Q1. There are 3120 counties and 18 industries. Standard errors presented in parentheses are clustered at the State-level. *,**, and ${ }^{* * *}$ denote significance at the $10 \%, 5 \%$, and $1 \%$, respectively.

\begin{tabular}{|c|c|c|c|c|}
\hline \multicolumn{5}{|c|}{$\begin{array}{l}\text { High versus low unemployment (2010) } C Z \\
\text { Above or below median }\end{array}$} \\
\hline & $\Delta \log \mathrm{e}$ & nployment & (2011Q1-2 & 014Q1) \\
\hline Treatment $\times$ high & $\begin{array}{c}0.015^{* * *} \\
(0.004)\end{array}$ & $\begin{array}{c}0.013^{* * *} \\
(0.004)\end{array}$ & $\begin{array}{c}0.015^{* * *} \\
(0.004)\end{array}$ & $\begin{array}{c}0.014^{* * *} \\
(0.004)\end{array}$ \\
\hline Treatment $\times$ low & $\begin{array}{c}0.006 \\
(0.005)\end{array}$ & $\begin{array}{c}0.004 \\
(0.004)\end{array}$ & $\begin{array}{c}0.006 \\
(0.005)\end{array}$ & $\begin{array}{c}0.005 \\
(0.004)\end{array}$ \\
\hline Treatment: $\mathrm{CZ} \times$ high & & & $\begin{array}{l}-0.003 \\
(0.003)\end{array}$ & $\begin{array}{l}-0.003 \\
(0.003)\end{array}$ \\
\hline Treatment: $\mathrm{CZ} \times$ low & & & $\begin{array}{l}-0.009^{*} \\
(0.005)\end{array}$ & $\begin{array}{l}-0.009^{*} \\
(0.005)\end{array}$ \\
\hline County $\times$ sector controls & Yes & Yes & Yes & Yes \\
\hline CZ controls & Yes & Yes & Yes & Yes \\
\hline Sector FE & No & Yes & No & Yes \\
\hline State FE & Yes & Yes & Yes & Yes \\
\hline Observations & 45318 & 45318 & 45318 & 45318 \\
\hline$R^{2}$ & 0.047 & 0.068 & 0.048 & 0.068 \\
\hline
\end{tabular}




\section{Appendix}

Can Paying Firms Quicker Affect Aggregate Employment? 
Panel A. Treated government contracts

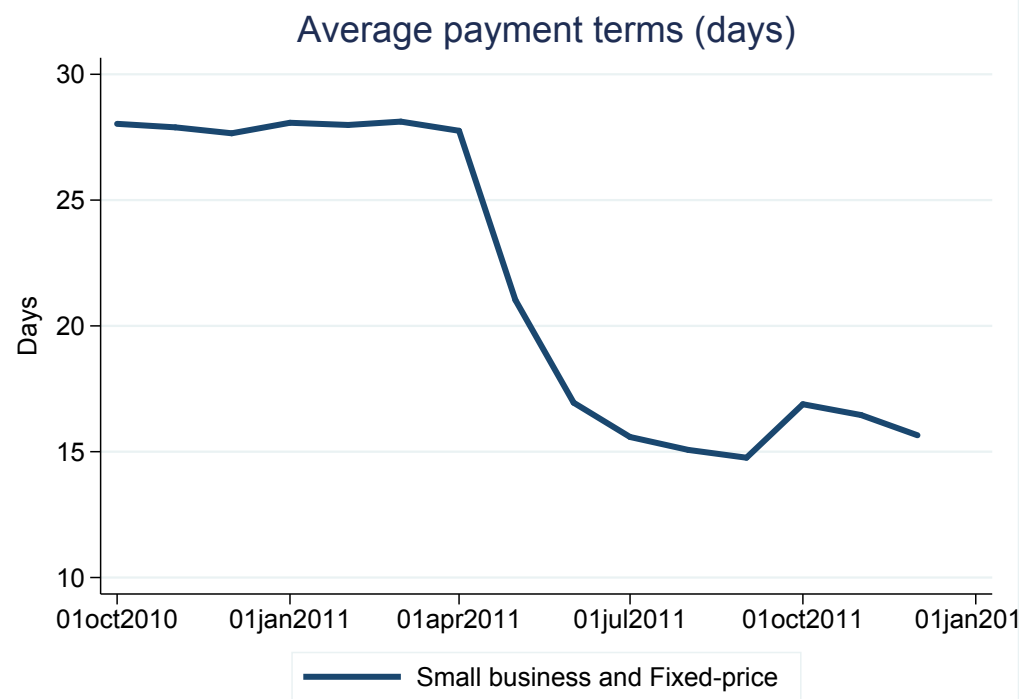

Panel B. Untreated government contracts

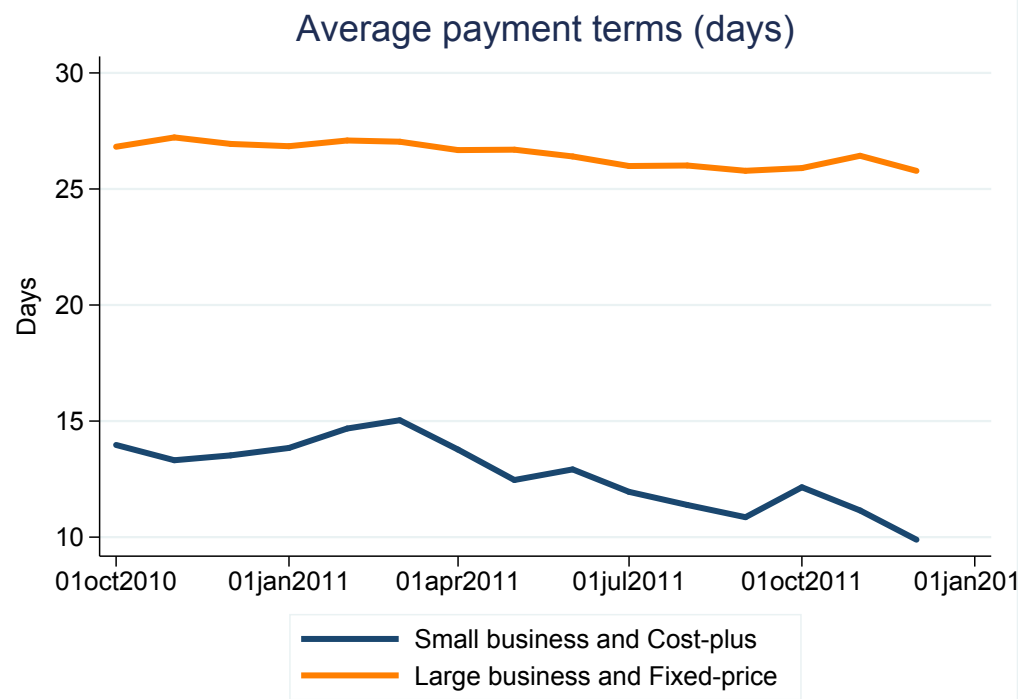

Figure A.1: Department of Defense payment terms. This figure shows the average number of days between receipt and payment of invoices in the MOCAS payment system of the Department of Defense. Panel A presents the difference between payments associated with contracts awarded to small versus large businesses. Panel B presents the difference between contracts awarded on fixed-price rather than a cost-plus basis. Under fixed-price contracts, contractors agree to deliver the product or service at a pre-negotiated price. Under cost-plus contracts, contractors are paid for their expenses up to a set limit, plus profit. 


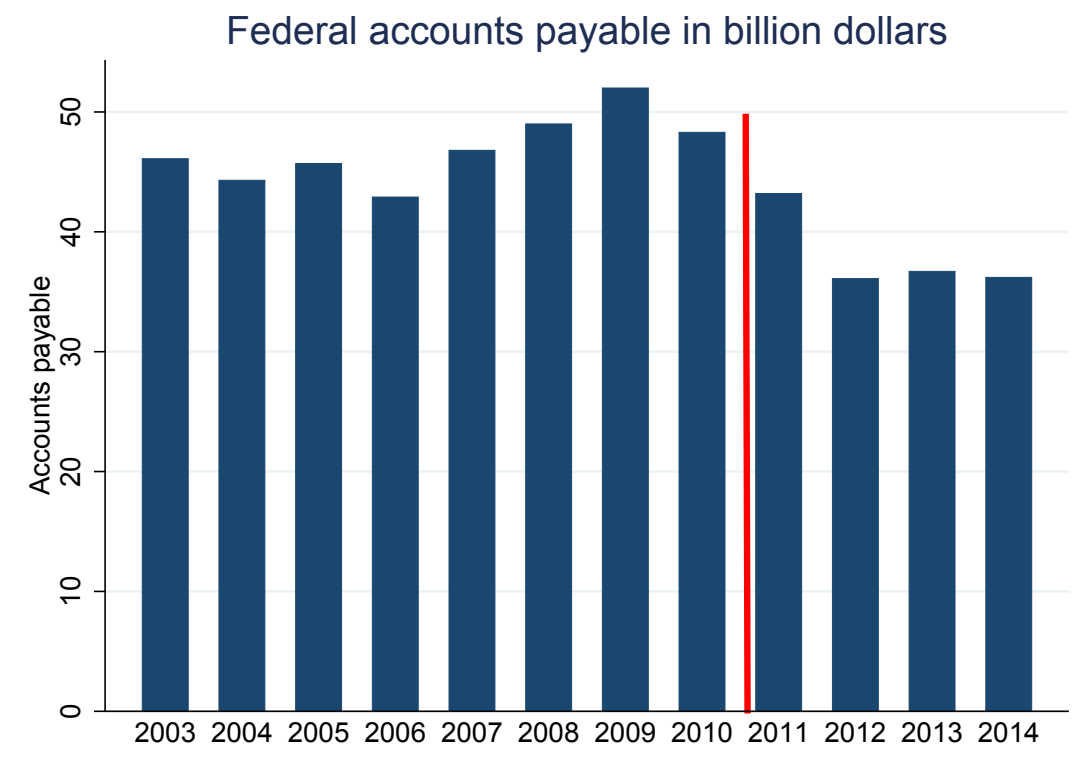

Figure A.2: US federal accounts payable. This figure presents total accounts payables across agencies of the US federal government for fiscal years 2003 to 2014, obtained from United States Government Notes to the Financial Statements. These aggregates exclude agencies that did not report payables consistently across the period.

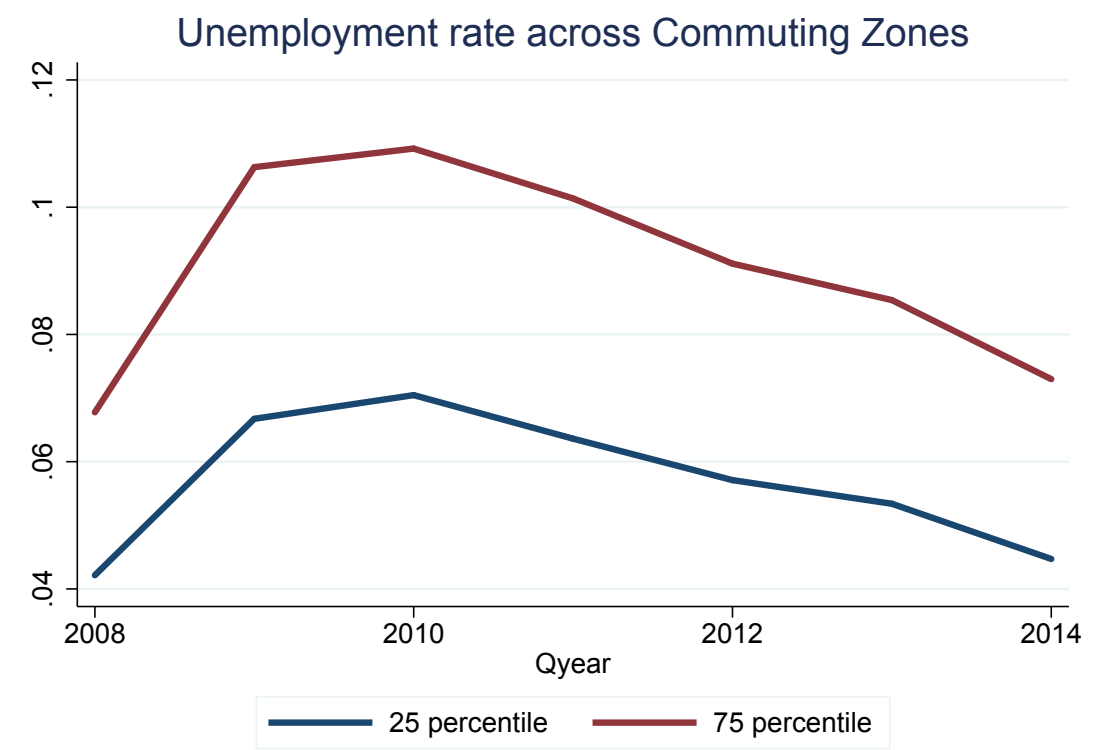

Figure A.3: Unemployment rates across CZs . This figure presents the 25th and 75 th percentile of the distribution of unemployment rates across commuting zones in the US, from 2008 to 2014. 
Table A.1: Change in government contract intensity

This table presents the results of a difference-in-difference estimation in first-differences. We run OLS regressions at the county $\times$ sector level of the change in average quarterly government contracts between the two year prior and the three years after the payment acceleration, scaled by 2011 payroll, on county $\times$ sector exposure to government contracts that were accelerated following the implementation of the federal payment reform of 2011. Treatment is the average quarterly amount of eligible government contracts to be performed in a given county $\times$ sector between 2009Q1-2011Q1, normalized by quarterly payrolls in 2011Q1. Control variables include the average quarterly amount of all government contracts to be performed in a given county $\times$ sector between 2009Q1-2011Q1, normalized by quarterly payrolls in 2011Q1, as well as additional county $\times$ sector controls including the share of small establishment, the log average establishment size, 2000Q1 to 2011Q1 average annual employment growth, the correlation of employment growth with aggregate employment growth, the log of total employment and the log average earnings. There are 3120 counties and 18 industries. Standard errors presented in parentheses are clustered at the State-level. ${ }^{*}, * *$, and ${ }^{* * *}$ denote significance at the $10 \%, 5 \%$, and $1 \%$, respectively.

\begin{tabular}{lccccc}
\hline \hline \multicolumn{1}{c}{$\Delta$ Average quarterly government contract, scaled by $2011 \mathrm{Q} 1$ payroll } \\
\hline \multirow{4}{*}{ Treatment } & & & & & \\
& 0.067 & 0.073 & 0.072 & 0.054 & 0.046 \\
& $(0.052)$ & $(0.051)$ & $(0.051)$ & $(0.053)$ & $(0.052)$ \\
County $\times$ sector controls & No & Yes & Yes & Yes & Yes \\
Sector FE & No & No & Yes & No & Yes \\
County FE & No & No & No & Yes & Yes \\
& & & & & \\
Observations & 45333 & 45333 & 45333 & 45333 & 45333 \\
$R^{2}$ & 0.283 & 0.284 & 0.290 & 0.349 & 0.356 \\
& & & & & \\
\hline \hline
\end{tabular}


Table A.2: Distribution of procurement contracts across sectors This table presents the cross-sector distribution of average yearly amounts of Government contracts granted between 2009 and 2014, in billion dollars. Eligible refers to all contracts but DOD cost-plus contracts. Ineligible refer to DOD cost-plus contracts. There are 18 industries.

\begin{tabular}{|c|c|c|c|c|c|}
\hline \multirow[b]{3}{*}{ Sector } & \multicolumn{5}{|c|}{ Average yearly amounts 2009-2014, in billion dollars } \\
\hline & \multirow[t]{2}{*}{ All businesses } & \multicolumn{2}{|c|}{ Small businesses } & \multicolumn{2}{|c|}{ Large businesses } \\
\hline & & Eligible & Ineligible & Eligible & Ineligible \\
\hline Manufacturing & 175.30 & 18.49 & 1.18 & 118.24 & 37.39 \\
\hline Professional services & 131.03 & 18.41 & 5.93 & 29.69 & 77.00 \\
\hline Admin & 42.58 & 5.63 & 0.41 & 11.53 & 25.01 \\
\hline Construction & 39.23 & 9.14 & 0.03 & 28.16 & 1.91 \\
\hline Wholesale & 20.81 & 4.91 & 0.33 & 12.00 & 3.57 \\
\hline Transportation & 14.39 & 2.07 & 0.03 & 9.57 & 2.73 \\
\hline Finance & 12.99 & 0.33 & 0.00 & 2.86 & 9.80 \\
\hline Information & 11.24 & 2.18 & 0.18 & 6.09 & 2.79 \\
\hline Health care & 5.97 & 1.28 & 0.01 & 4.13 & 0.55 \\
\hline Education & 4.70 & 0.91 & 0.03 & 1.83 & 1.92 \\
\hline Retail & 3.90 & 1.24 & 0.30 & 1.94 & 0.42 \\
\hline Other services & 3.37 & 0.58 & 0.02 & 1.51 & 1.27 \\
\hline Real estate & 3.33 & 1.37 & 0.00 & 1.89 & 0.07 \\
\hline Utilities & 2.30 & 0.17 & 0.00 & 1.90 & 0.23 \\
\hline Accomodation & 1.09 & 0.22 & 0.01 & 0.80 & 0.06 \\
\hline Agriculture & 0.43 & 0.30 & 0.01 & 0.05 & 0.07 \\
\hline Mining & 0.34 & 0.09 & -0.00 & 0.21 & 0.04 \\
\hline Arts & 0.07 & 0.04 & 0.00 & 0.03 & 0.00 \\
\hline
\end{tabular}


Table A.3: Top and bottom 20 4-digit NAICS industries

This tabe presents the top 20 and bottom 20 4-digit NAICS industries based on treatment, measured as the average quarterly amount of eligible government contracts to be performed in a given industry between 2009Q1-2011Q1, normalized by quarterly payroll in 2011Q1 . There are 287 4-digit NAICS industries.

\begin{tabular}{|c|c|c|}
\hline Rank & Naics 4 & Description \\
\hline 1 & 3159 & Apparel Accessories and Other Apparel Manufacturing \\
\hline 2 & 1153 & Support Activities for Forestry \\
\hline 3 & 3366 & Ship and Boat Building \\
\hline 4 & 2379 & Other Heavy and Civil Engineering Construction \\
\hline 5 & 5629 & Remediation and Other Waste Management Services \\
\hline 6 & 5612 & Facilities Support Services \\
\hline 7 & 2362 & Nonresidential Building Construction \\
\hline 8 & 3149 & Other Textile Product Mills \\
\hline 9 & 6114 & Business Schools and Computer and Management Training \\
\hline 10 & 4247 & Petroleum and Petroleum Products Merchant Wholesalers \\
\hline 11 & 4812 & Nonscheduled Air Transportation \\
\hline 12 & 3162 & Footwear Manufacturing \\
\hline 13 & 4831 & Deep Sea, Coastal, and Great Lakes Water Transportation \\
\hline 14 & 3112 & Grain and Oilseed Milling \\
\hline 15 & 5311 & Lessors of Real Estate \\
\hline 16 & 3333 & Commercial and Service Industry Machinery Manufacturing \\
\hline 17 & 3169 & Other Leather and Allied Product Manufacturing \\
\hline 18 & 3329 & Other Fabricated Metal Product Manufacturing \\
\hline 19 & 3325 & Hardware Manufacturing \\
\hline 20 & 2373 & Highway, Street, and Bridge Construction \\
\hline 267 & 5221 & Depository Credit Intermediation \\
\hline 268 & 2121 & Coal Mining \\
\hline 269 & 8132 & Grantmaking and Giving Services \\
\hline 270 & 4862 & Pipeline Transportation of Natural Gas \\
\hline 271 & 6223 & Specialty (except Psychiatric and Substance Abuse) Hospitals \\
\hline 272 & 5331 & Lessors of Nonfinancial Intangible Assets (except Copyrighted Works) \\
\hline 273 & 3274 & Lime and Gypsum Product Manufacturing \\
\hline 274 & 7131 & Amusement Parks and Arcades \\
\hline 275 & 4453 & Beer, Wine, and Liquor Stores \\
\hline 276 & 4248 & Beer, Wine, and Distilled Alcoholic Beverage Merchant Wholesalers \\
\hline 277 & 4521 & Department Stores \\
\hline 278 & 3122 & Tobacco Manufacturing \\
\hline 279 & 7132 & Gambling Industries \\
\hline 280 & 4879 & Scenic and Sightseeing Transportation, Other \\
\hline 281 & 4861 & Pipeline Transportation of Crude Oil \\
\hline 282 & 5211 & Monetary Authorities-Central Bank \\
\hline 283 & 2122 & Metal Ore Mining \\
\hline 284 & 7224 & Drinking Places (Alcoholic Beverages) \\
\hline 285 & 5232 & Securities and Commodity Exchanges \\
\hline 286 & 5259 & Other Investment Pools and Funds \\
\hline 287 & 4869 & Other Pipeline Transportation \\
\hline
\end{tabular}


Table A.4: Top and bottom 20 County $\times$ 2-digit NAICS industries

This tabe presents the top 20 and bottom 20 county $\times$ sectors based on treatment, measured as the average quarterly amount of eligible government contracts to be performed in a given county $\times$ sector between 2009Q1-2011Q1, normalized by quarterly payroll in 2011Q1. There are 3120 counties and 18 industries, and a total of 45333 county $\times$ sectors.

\begin{tabular}{|c|c|c|c|}
\hline Rank & 2-digit NAICS & County & State \\
\hline 1 & Agriculture & Sweetwater County & WY \\
\hline 2 & Real estate & Bradford County & $\mathrm{FL}$ \\
\hline 3 & Real estate & Craig County & $\mathrm{OK}$ \\
\hline 4 & Administrative and support & Miami County & IN \\
\hline 5 & Professional services & Garfield County & UT \\
\hline 6 & Construction & Lake County & OR \\
\hline 7 & Real estate & Brewster County & TX \\
\hline 8 & Wholesale & Virginia Beach city & VA \\
\hline 9 & Information & Ontario County & NY \\
\hline 10 & Professional services & Ste. Genevieve County & MO \\
\hline 11 & Construction & Catron County & NM \\
\hline 12 & Manufacturing & McCreary County & KY \\
\hline 13 & Education & Shelby County & KY \\
\hline 14 & Administrative and support & Accomack County & VA \\
\hline 15 & Education & Dougherty County & GA \\
\hline 16 & Administrative and support & Gooding County & ID \\
\hline 17 & Transportation & Valley County & ID \\
\hline 18 & Construction & Socorro County & NM \\
\hline 19 & Administrative and support & Humphreys County & MS \\
\hline 20 & Mining & Otero County & NM \\
\hline 45313 & Manufacturing & Hidalgo County & TX \\
\hline 45314 & Education & Walker County & $\mathrm{AL}$ \\
\hline 45315 & Accommodation & Cape May County & NJ \\
\hline 45316 & Administrative and support & York County & $\mathrm{PA}$ \\
\hline 45317 & Professional services & Wilcox County & $\mathrm{AL}$ \\
\hline 45318 & Real estate & St. James Parish & LA \\
\hline 45319 & Administrative and support & St. Charles Parish & $\mathrm{LA}$ \\
\hline 45320 & Professional services & Nelson County & ND \\
\hline 45321 & Real estate & Avoyelles Parish & LA \\
\hline 45322 & Administrative and support & Jefferson Parish & LA \\
\hline 45323 & Administrative and support & McKenzie County & ND \\
\hline 45324 & Mining & Carbon County & WY \\
\hline 45325 & Construction & Dixie County & $\mathrm{FL}$ \\
\hline 45326 & Arts & Park County & $\mathrm{WY}$ \\
\hline 45327 & Real estate & Cullman County & $\mathrm{AL}$ \\
\hline 45328 & Professional services & Ingham County & MI \\
\hline 45329 & Real estate & Evangeline Parish & $\mathrm{LA}$ \\
\hline 45330 & Education & Anderson County & $\mathrm{TN}$ \\
\hline 45331 & Information & Leon County & FL \\
\hline 45332 & Mining & Fairfield County & $\mathrm{CT}$ \\
\hline 45333 & Arts & Madison County & $\mathrm{AL}$ \\
\hline
\end{tabular}


Table A.5: Robustness: Baseline using alternative specifications

This table presents alternative specifications. Panel A presents a difference-in-difference estimation of the three year change in log payroll on the interaction of a post dummy taking the value of one for the 2011-14 period, and zero for the 2008-11 period with a treatment variable measured as the average quarterly amount of eligible government contracts to be performed in a given county $\times$ sector between 2009Q1-2011Q1, normalized by quarterly payrolls in 2011Q1. Panel B presents OLS regressions of the change in log payroll on a dummy taking the value of one for county $\times$ sector with treatment above the sample median. Control variables include the average quarterly amount of all government contracts to be performed in a given county $\times$ sector between 2009Q1-2011Q1, normalized by quarterly payrolls in 2011Q1, as well as additional county $\times$ sector controls including the share of small establishment, the log average establishment size, 2000Q1 to 2011Q1 average annual employment growth, the corr elation of employment growth with aggregate employment growth, the log of total employment and the log average earnings. There are 3120 counties and 18 industries. Standard errors presented in parentheses are clustered at the State-level. ${ }^{*}, * *$, and $* * *$ denote significance at the $10 \%, 5 \%$, and $1 \%$, respectively.

\begin{tabular}{|c|c|c|c|c|c|}
\hline \multirow[b]{2}{*}{ Post $\times$ Treatment } & \multicolumn{5}{|c|}{ Panel A: two period DID, 2008-11, 2011-14 } \\
\hline & $\begin{array}{c}0.144^{* * *} \\
(0.052)\end{array}$ & $\begin{array}{l}0.131^{* *} \\
(0.051)\end{array}$ & $\begin{array}{c}0.153^{* * *} \\
(0.054)\end{array}$ & $\begin{array}{c}0.139^{* * *} \\
(0.052)\end{array}$ & $\begin{array}{c}0.095^{*} \\
(0.051)\end{array}$ \\
\hline County $\times$ sector controls & Yes & Yes & Yes & Yes & Yes \\
\hline County $\times$ sector FE & Yes & Yes & Yes & Yes & Yes \\
\hline Sector $\times$ year FE & No & Yes & No & Yes & Yes \\
\hline State $\times$ year FE & No & No & Yes & Yes & Yes \\
\hline Post $\times$ County $\times$ sector controls & Yes & Yes & Yes & Yes & Yes \\
\hline Observations & 91850 & 91850 & 91850 & 91850 & 91850 \\
\hline \multirow[t]{2}{*}{$R^{2}$} & 0.795 & 0.798 & 0.817 & 0.819 & 0.822 \\
\hline & \multicolumn{5}{|c|}{ Panel B: dummy for high versus low treatment } \\
\hline High treatment & $\begin{array}{c}0.004 \\
(0.006)\end{array}$ & $\begin{array}{c}0.024^{* * *} \\
(0.006)\end{array}$ & $\begin{array}{c}0.017^{* * *} \\
(0.006)\end{array}$ & $\begin{array}{c}0.031^{* * *} \\
(0.006)\end{array}$ & $\begin{array}{c}0.015^{* * *} \\
(0.006)\end{array}$ \\
\hline County $\times$ sector controls & No & Yes & Yes & Yes & Yes \\
\hline Sector FE & No & No & Yes & No & Yes \\
\hline County FE & No & No & No & Yes & Yes \\
\hline Observations & 45333 & 45333 & 45333 & 45333 & 45333 \\
\hline$R^{2}$ & 0.003 & 0.041 & 0.060 & 0.155 & 0.178 \\
\hline
\end{tabular}


Table A.6: Robustness: Baseline results using 2011Q2-2014Q1 government contracts This table presents the results of a difference-in-difference estimation in first-differences. We run OLS regressions at the county $\times$ sector level of the change in log payroll on county $\times$ sector exposure to government contracts that were accelerated following the implementation of the federal payment reform of 2011. Treatment is the average quarterly amount of eligible government contracts to be performed in a given county $\times$ sector between 2011Q1-2014Q1, normalized by quarterly payrolls in 2011Q1. Control variables include the average quarterly amount of all government contracts to be performed in a given county $\times$ sector between 2009Q1-2011Q1, normalized by quarterly payrolls in 2011Q1, as well as additional county $\times$ sector controls including the share of small establishment, the log average establishment size, 2000Q1 to 2011Q1 average annual employment growth, the correlation of employment growth with aggregate employment growth, the log of total employment and the log average earnings. There are 3120 counties and 18 industries. Standard errors presented in parentheses are clustered at the State-level. *, ${ }^{* *}$, and ${ }^{* * *}$ denote significance at the $10 \%, 5 \%$, and $1 \%$, respectively.

\begin{tabular}{|c|c|c|c|c|c|}
\hline \multirow[b]{2}{*}{ Treatment } & \multicolumn{5}{|c|}{ Panel A: $\Delta$ log payroll (2011Q1-2014Q1) } \\
\hline & $\begin{array}{c}0.200^{* * *} \\
(0.040)\end{array}$ & $\begin{array}{c}0.120^{* * *} \\
(0.038)\end{array}$ & $\begin{array}{c}0.096^{* *} \\
(0.040)\end{array}$ & $\begin{array}{c}0.138^{* * *} \\
(0.041)\end{array}$ & $\begin{array}{c}0.083^{* *} \\
(0.040)\end{array}$ \\
\hline County $\times$ sector controls & No & Yes & Yes & Yes & Yes \\
\hline Sector FE & No & No & Yes & No & Yes \\
\hline County FE & No & No & No & Yes & Yes \\
\hline Observations & 45333 & 45333 & 45333 & 45333 & 45333 \\
\hline$R^{2}$ & 0.002 & 0.045 & 0.059 & 0.147 & 0.166 \\
\hline \multicolumn{6}{|l|}{ hline } \\
\hline & \multicolumn{5}{|c|}{ Panel B: $\Delta$ log employment (2011Q1-2014Q1) } \\
\hline Treatment & $\begin{array}{c}0.129^{* * *} \\
(0.032)\end{array}$ & $\begin{array}{c}0.086^{* * *} \\
(0.031)\end{array}$ & $\begin{array}{c}0.065^{* *} \\
(0.031)\end{array}$ & $\begin{array}{c}0.103^{* * *} \\
(0.036)\end{array}$ & $\begin{array}{c}0.053 \\
(0.035)\end{array}$ \\
\hline County $\times$ sector controls & No & Yes & Yes & Yes & Yes \\
\hline Sector FE & No & No & Yes & No & Yes \\
\hline County FE & No & No & No & Yes & Yes \\
\hline Observations & 45333 & 45333 & 45333 & 45333 & 45333 \\
\hline$R^{2}$ & 0.001 & 0.037 & 0.056 & 0.132 & 0.157 \\
\hline \multicolumn{6}{|l|}{ hline } \\
\hline & \multicolumn{5}{|c|}{ Panel C: $\Delta$ log earnings (2011Q1-2014Q1) } \\
\hline Treatment & $\begin{array}{c}0.071^{* * *} \\
(0.021)\end{array}$ & $\begin{array}{c}0.034 \\
(0.021)\end{array}$ & $\begin{array}{c}0.032 \\
(0.023)\end{array}$ & $\begin{array}{c}0.035 \\
(0.021)\end{array}$ & $\begin{array}{c}0.030 \\
(0.022)\end{array}$ \\
\hline County $\times$ sector controls & No & Yes & Yes & Yes & Yes \\
\hline Sector FE & No & No & Yes & No & Yes \\
\hline County FE & No & No & No & Yes & Yes \\
\hline Observations & 45333 & 45333 & 45333 & 45333 & 45333 \\
\hline$R^{2}$ & 0.001 & 0.083 & 0.142 & 0.162 & 0.221 \\
\hline
\end{tabular}


Table A.7: Robustness: County $\times$ four-digit sector

This table presents the results of a difference-in-difference estimation in first-differences. We run OLS regressions at the county $\times 4$-digit sector level of the change in log payroll on county $\times$ sector exposure to government contracts that were accelerated following the implementation of the federal payment reform of 2011. Treatment is the average quarterly amount of eligible government contracts to be performed in a given county $\times$ sector between 2009Q1-2011Q1, normalized by quarterly payrolls in 2011Q1. Control variables include the average quarterly amount of all government contracts to be performed in a given county $\times$ sector between 2009Q1-2011Q1, normalized by quarterly payrolls in 2011Q1, as well as additional county $\times$ sector controls including the share of small establishment, the log average establishment size, 2000Q1 to 2011Q1 average annual employment growth, the correlation of employment growth with aggregate employment growth, the log of total employment and the log average earnings. There are 3120 counties and 18 industries. Standard errors presented in parentheses are clustered at the State-level. *, $* *$, and ${ }^{* * *}$ denote significance at the $10 \%, 5 \%$, and $1 \%$, respectively.

\begin{tabular}{|c|c|c|c|c|c|}
\hline \multirow[b]{2}{*}{ Treatment } & \multicolumn{5}{|c|}{$\Delta$ log payroll (2011Q1-2014Q1) } \\
\hline & $\begin{array}{c}0.052^{* * *} \\
(0.010)\end{array}$ & $\begin{array}{c}0.031^{* * *} \\
(0.009)\end{array}$ & $\begin{array}{c}0.033^{* * *} \\
(0.009)\end{array}$ & $\begin{array}{c}0.027^{* * *} \\
(0.009)\end{array}$ & $\begin{array}{c}0.077^{* * *} \\
(0.025)\end{array}$ \\
\hline County $\times$ sector controls & No & Yes & Yes & Yes & Yes \\
\hline Sector (4 digit) FE & No & No & Yes & No & Yes \\
\hline County FE & No & No & No & Yes & Yes \\
\hline Observations & 269283 & 269283 & 269283 & 269283 & 269332 \\
\hline$R^{2}$ & 0.004 & 0.049 & 0.077 & 0.075 & 0.162 \\
\hline
\end{tabular}


Table A.8: Employment growth: job creations and destructions

This table presents the results of a difference-in-difference estimation in first-differences. We run OLS regressions at the county $\times$ two-digit sector level of average quarterly job creations and job destruction rates on county $\times$ sector exposure to government contracts that were accelerated following the implementation of the federal payment reform of 2011 . Treatment is the average quarterly amount of eligible government contracts to be performed in a given county $\times$ sector between 2009Q1-2011Q1, normalized by quarterly payrolls in 2011Q1. Control variables include the average quarterly amount of all government contracts to be performed in a given county $\times$ sector between 2009Q1-2011Q1, normalized by quarterly payrolls in 2011Q1, as well as additional county $\times$ sector controls including the share of small establishment, the $\log$ average establishment size, 2000Q1 to 2011Q1 average annual employment growth, the correlation of employment growth with aggregate employment growth, the log of total employment and the log average earnings. There are 3120 counties and 18 industries. Standard errors presented in parentheses are clustered at the State-level. *, **, and ${ }^{* * *}$ denote significance at the $10 \%, 5 \%$, and $1 \%$, respectively.

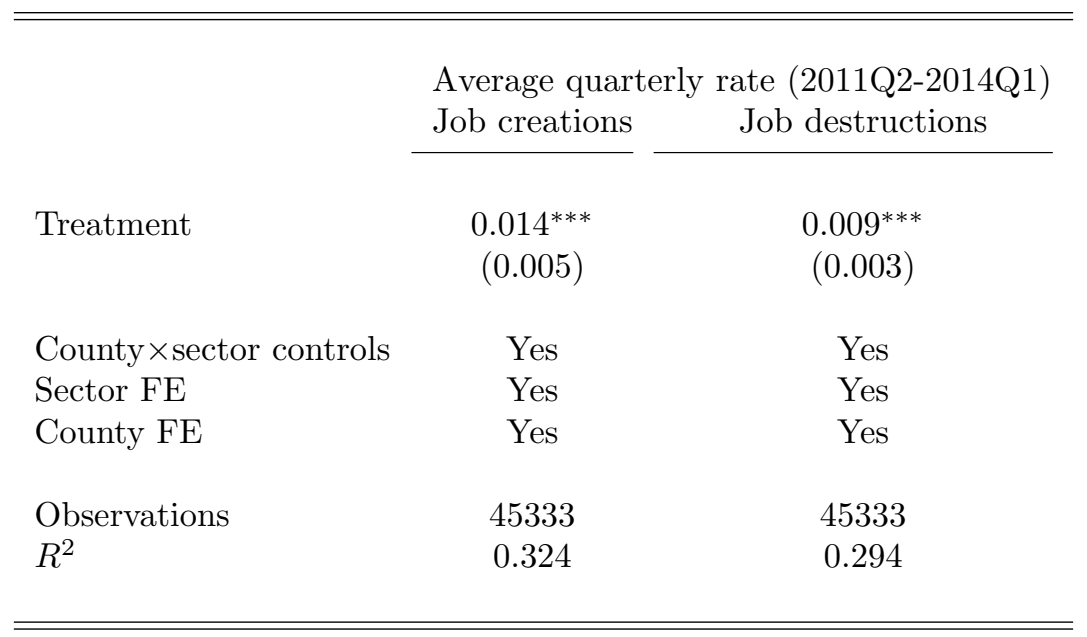


Table A.9: Earnings growth: new and existing workers

This table presents the results of a difference-in-difference estimation in first-differences. We run OLS regressions at the county $\times$ sector level of the change in log earnings for new hires and existing workers on county $\times$ sector exposure to government contracts that were accelerated following the implementation of the federal payment reform of 2011. Treatment is the average quarterly amount of eligible government contracts to be performed in a given county $\times$ sector between 2009Q1-2011Q1, normalized by quarterly payrolls in 2011Q1. Control variables include the average quarterly amount of all government contracts to be performed in a given county $\times$ sector between 2009Q1-2011Q1, normalized by quarterly payrolls in 2011Q1, as well as additional county $\times$ sector controls including the share of small establishment, the log average establishment size, 2000Q1 to 2011Q1 average annual employment growth, the correlation of employment growth with aggregate employment growth, the $\log$ of total employment and the $\log$ average earnings. There are 3120 counties and 18 industries. Standard errors presented in parentheses are clustered at the State-level. ${ }^{*}, * *$, and ${ }^{* * *}$ denote significance at the $10 \%, 5 \%$, and $1 \%$, respectively.

\begin{tabular}{|c|c|c|c|}
\hline \multirow[b]{3}{*}{ Treatment } & \multicolumn{3}{|c|}{$\Delta$ log earnings (2011Q1-2014Q1) } \\
\hline & All & New hires & Existing workers \\
\hline & $\begin{array}{c}0.035^{* *} \\
(0.017)\end{array}$ & $\begin{array}{c}0.059 \\
(0.049)\end{array}$ & $\begin{array}{c}0.025 \\
(0.015)\end{array}$ \\
\hline County $\times$ sector controls & Yes & Yes & Yes \\
\hline Sector FE & Yes & Yes & Yes \\
\hline County FE & Yes & Yes & Yes \\
\hline Observations & 45333 & 41634 & 35884 \\
\hline$R^{2}$ & 0.221 & 0.109 & 0.222 \\
\hline
\end{tabular}


Table A.10: Employment effects at aggregated levels

This table presents the results of a difference-in-difference estimation in first-differences. We run OLS regressions at the commuting zone level of the change in log payroll on commuting zone exposure to government contracts that were accelerated following the implementation of the federal payment reform of 2011. Treatment is the average quarterly amount of eligible government contracts to be performed in a given commuting zone between 2009Q1-2011Q1, normalized by quarterly payrolls in 2011Q1. Control variables include the average quarterly amount of all government contracts to be performed in a given commuting zone between 2009Q1-2011Q1, normalized by quarterly payrolls in 2011Q1, as well as additional commuting zone level controls including the share of small establishment, the log average establishment size, 2000Q1 to 2011Q1 average annual employment growth, the correlation of employment growth with aggregate employment growth, the log of total employment and the log average earnings. There are 703 commuting zones. Robust standard errors presented in parentheses. ${ }^{*},{ }^{* *}$, and ${ }^{* *}$ denote significance at the $10 \%, 5 \%$, and $1 \%$, respectively.

\begin{tabular}{|c|c|c|c|}
\hline & \multicolumn{3}{|c|}{$\Delta$ log employment (2011Q1-2014Q1) } \\
\hline & All & $\begin{array}{c}\text { High CZ } \\
\text { unemployment }\end{array}$ & $\begin{array}{c}\text { Low CZ } \\
\text { unemployment }\end{array}$ \\
\hline Treatment & $\begin{array}{c}0.148 \\
(0.145)\end{array}$ & $\begin{array}{l}0.368^{* *} \\
(0.171)\end{array}$ & $\begin{array}{l}-0.013 \\
(0.226)\end{array}$ \\
\hline CZ level controls & Yes & Yes & Yes \\
\hline $\begin{array}{l}\text { Observations } \\
R^{2}\end{array}$ & $\begin{array}{c}703 \\
0.178\end{array}$ & $\begin{array}{c}350 \\
0.265\end{array}$ & $\begin{array}{c}353 \\
0.312\end{array}$ \\
\hline
\end{tabular}


Table A.11: Spillover effect of payment acceleration: tradable and non tradables This table presents the results of a difference-in-difference estimation in first-differences. We run OLS regressions at the county $\times$ sector level of the change in log payroll on county $\times$ sector exposure to government contracts that were accelerated following the implementation of the federal payment reform of 2011. Treatment is the average quarterly amount of eligible government contracts to be performed in a given county $\times$ sector between 2009Q1-2011Q1, normalized by quarterly payrolls in 2011Q1. Treatment: $C Z$ is the same variable, measured at the commuting zone level rather than the county $\times$ sector level, and excluding the focal county $\times$ sector. Treatment and Treatment: $C Z$ are normalized by their crosssectional standard deviation. County $\times$ sector control variables include the average quarterly amount of all government contracts to be performed in a given county $\times$ sector between 2009Q1-2011Q1, normalized by quarterly payrolls in 2011Q1, as well as additional county $\times$ sector controls including the share of small establishment, the log average establishment size, 2000Q1 to 2011Q1 average annual employment growth, the correlation of employment growth with aggregate employment growth, the log of total employment and the log average earnings. CZ controls include the unemployment rate, the share of small establishments, the log average establishment size, log total employment and log average earnings in 2011Q1. Non-tradable industries include health care, hospitality, food service, education, retail, and construction. There are 3120 counties and 18 industries. Standard errors presented in parentheses are clustered at the State-level. ${ }^{*}, * *$, and ${ }^{* * *}$ denote significance at the $10 \%, 5 \%$, and $1 \%$, respectively.

\begin{tabular}{lcc}
\hline \hline & \multicolumn{2}{c}{$\Delta$ log employment $(2011 \mathrm{Q} 1-2014 \mathrm{Q} 1)$} \\
\cline { 2 - 3 } & & \\
Treatment: $\mathrm{CZ} \times$ Non-tradable & -0.001 & -0.002 \\
& $(0.003)$ & $(0.003)$ \\
Treatment: CZ $\times$ Tradable & $-0.009^{* *}$ & $-0.008^{* *}$ \\
& $(0.004)$ & $(0.004)$ \\
County $\times$ sector controls & & \\
CZ controls & Yes & Yes \\
Sector FE & Yes & Yes \\
State FE & No & Yes \\
& Yes & Yes \\
Observations & & \\
$R^{2}$ & 45318 & 45318 \\
\hline \hline
\end{tabular}

